\title{
APPLICATION OF VIBRATORS FOR MEASURING MORTAR CONSISTENCY AND FABRICATING MORTAR CUBES
}

\author{
By Raymond L. Blaine and John Tucker, Jr.
}

\section{ABSTRACT}

Two vibrators-one magnetic, with linear vertical motion; one mechanical with rotary horizontal motion-were employed to compact mortars of varying compositions, for various durations and at various frequencies and amplitudes. The effectiveness of the treatment was judged by (1) the reproducibility of the average strength of the six cubes in one batch, (2) the reproducibility of the strengths of individual specimens, and (3) the appearance of the compacted specimen. Standard Ottawa sand mortars possessed advantages over those with two or more types of aggregate. The mechanical rotary vibrator, designed for the investigation, was found to give better results than the magnetic vibrator. Either vibrator may be used to measure the consistencies of mortars of the dryness suitable for compaction by vibration.

\section{CONTENTS}

I. Introduction

II. Apparatus and materials

1. Electromagnetic vibrator

2. Rotary vibrator. 106

III. Materials and specimens

IV. Tests _._.

1. Movement of mortar in mold (rotary vibrator)

(a) Study of movement by stratified mortars ......... 108

(b) Study of rotation of mortars

2. Flow of mortars on flow table and on vibrators _. . . . . . 109

(a) Flow on a flat plate........ 109

(b) Flow in a V-trough 112

3. Nonhomogeneous compaction of mortars

4. Strength of specimens

(a) Reproducibility of strength - theory of measurement

(b) Hand-compacted specimens

(c) Mortar specimens compacted by vibration

(1) Study of different aggregates and proportions_ 115

(2) Effect of duration, amplitude, and frequency of

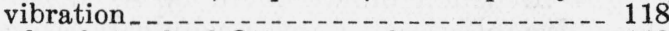

(3) Study of standard Ottawa sand mortars..... 118

V. Summary and conclusions ...

VI. References

\section{INTRODUCTION}

The comparatively large variation in the values obtained in any of the physical tests of cement may be attributed at least in part to the human equation. Test results vary, not only between laboratories, but with different operators in the same laboratory and with the same operator from day to day and throughout the day. One of the variable 
factors, but by no means the only one, which contributes to the differences in strength is the molding of the test specimens. In Europe, mechanically driven hammers or tampers have long been used to compact the mortar in an attempt to partially eliminate the personal equation. Experiments have been made with many different types of mechanical placing equipment [1,2,3].* Glanville [3] used a mechanically driven vibrator to compact the mortar cubes and obtained results more consistent than those usually obtained and also more indicative of the strengths that would be obtained with the same cements in concrete. There has also been a great deal of work done with mortars in an attempt to find some aggregates and gradings which are more suitable than those at present in use.

The investigation described in this paper had as its object the study of the strength and the strength reproducibility of mortars of various proportions and degrees of wetness when they were compacted by vibration. Hand fabricated mortar and concrete were made with the same cements for comparison.

\section{APPARATUS AND MATERIALS}

Two vibrators were used-an electromagnetic vibrator giving a simple harmonic motion along a vertical line, and a rotary vibrator giving a circular motion in a horizontal plane.

\section{ELECTROMAGNETIC VIBRATOR}

The electromagnetic vibrator was a commercial barrel packer, schematically shown in figure 1. The vibrating "head" of the machine is suspended by leaf springs, known as vibrator bars. An electromagnet to which alternating current is supplied attracts an armature fixed to these bars twice each cycle. This causes an attraction for both the positive and the negative halves of the wave; thus with 60 -cycle current the frequency of vibration is $120 \mathrm{c} / \mathrm{s}$. A rheostat in series with the electromagnet is used for varying the amplitude.

The vibrator had a sharp resonance characteristic. Changing the weight of the table by clamping one cube mold to it reduced the amplitude from its peak to so low a value that it could no longer be satisfactorily used for compacting specimens. On the other hand, if a body weighing several hundred pounds were placed on the vibrator and not fixed to the vibrating table, the amplitude would be adequate for compaction. In order to obtain an adequate amplitude with cube molds bolted to the head, it was therefore necessary to remove the head of the barrel packer and substitute a head of less weight to which molds could be fixed, so that the combined weight of head, molds, and mortar would be approximately that required to produce resonance. It was found necessary to work on one side of and just off the sharp resonance peak in order to obtain reproducible amplitudes. Figure 2 gives the resonance curve with the amplitude of vibration as a function of the table weight for a constant voltage producing a maximum amplitude of 0.021 in. This exceeds the maximum amplitude of 0.0156 in. recommended by the manufacturer of the machine in order that the safe armature clearance be not exceeded. It should be remembered in this connection that a small armature clearance is required for efficiency in an electromagnetic vibrator.

\footnotetext{
*Figures in brackets indicate the literature references at the end of this paper.
} 
The molds were centered on the vibrating table. When mortar was placed in the molds, the amplitude was at first the same as that obtained with the empty molds; but as compaction was attained,

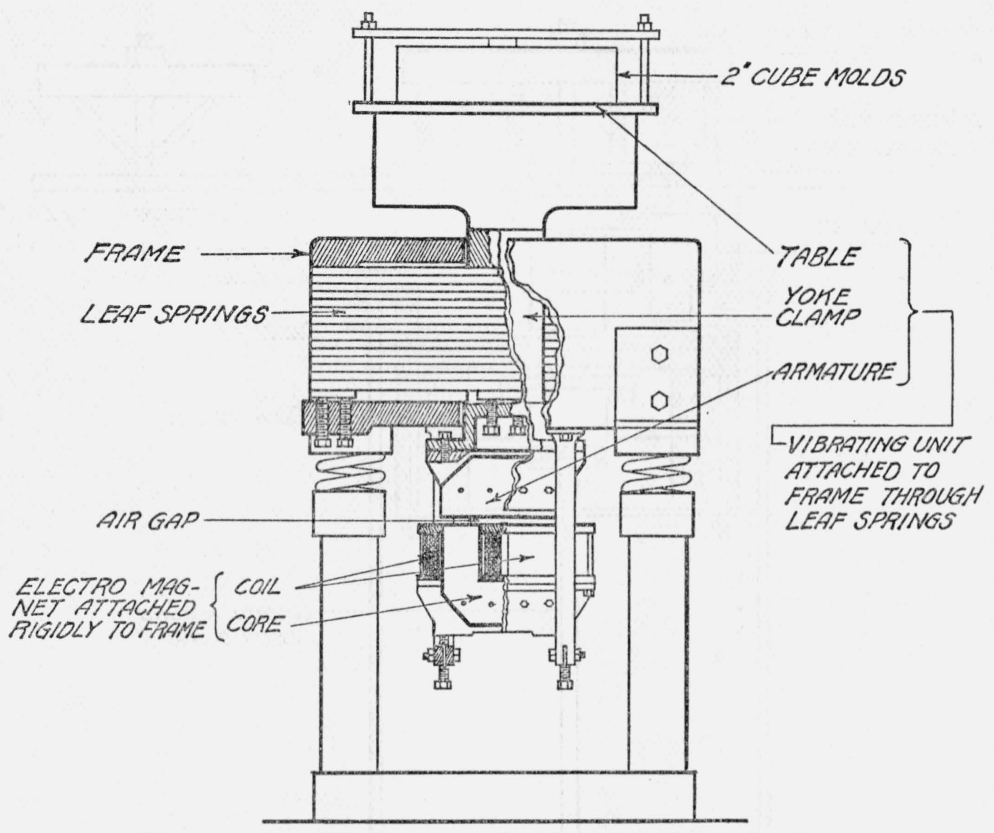

FigURe 1.-Electromagnetic vibrator, schematic view.

the mortar became a part of the vibrating unit and, like a weight rigidly fixed to the head, reduced the amplitude of the vibrator. The

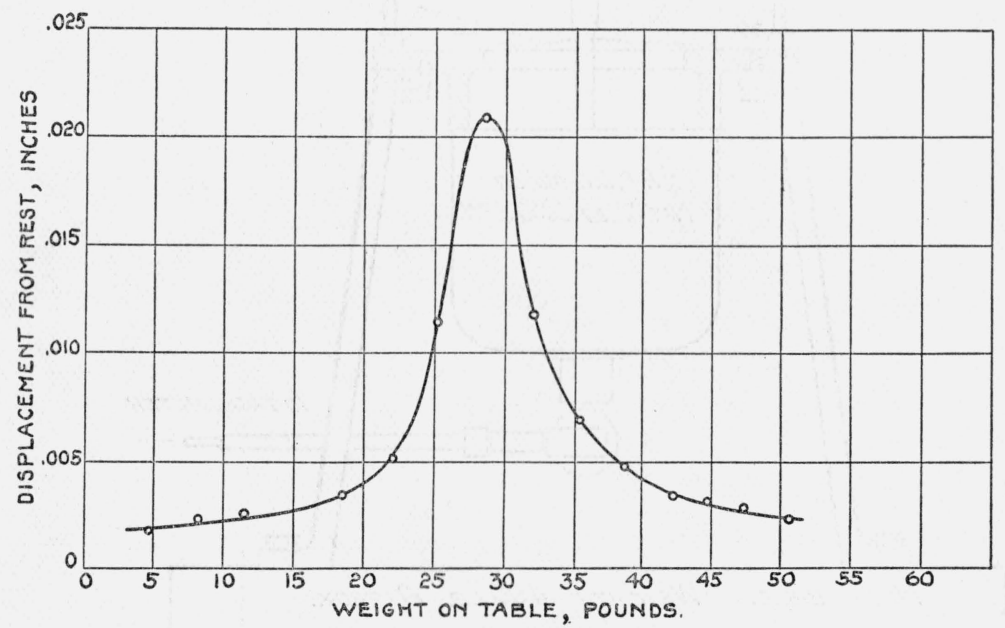

FIGURE 2.-Resonance curve, electromagnetic vibrator: relation between amplitude and weight on table.

vibrator, as contrasted with the motor-driven type, had the desirable characteristic of immediately attaining its full frequency and amplitude. 


\section{ROTARY VIBRATOR}

The rotary vibrator, figure 3 , designed for the present investigation, consisted of a circular vibrating table supported by six $1 / 4-\mathrm{in}$.

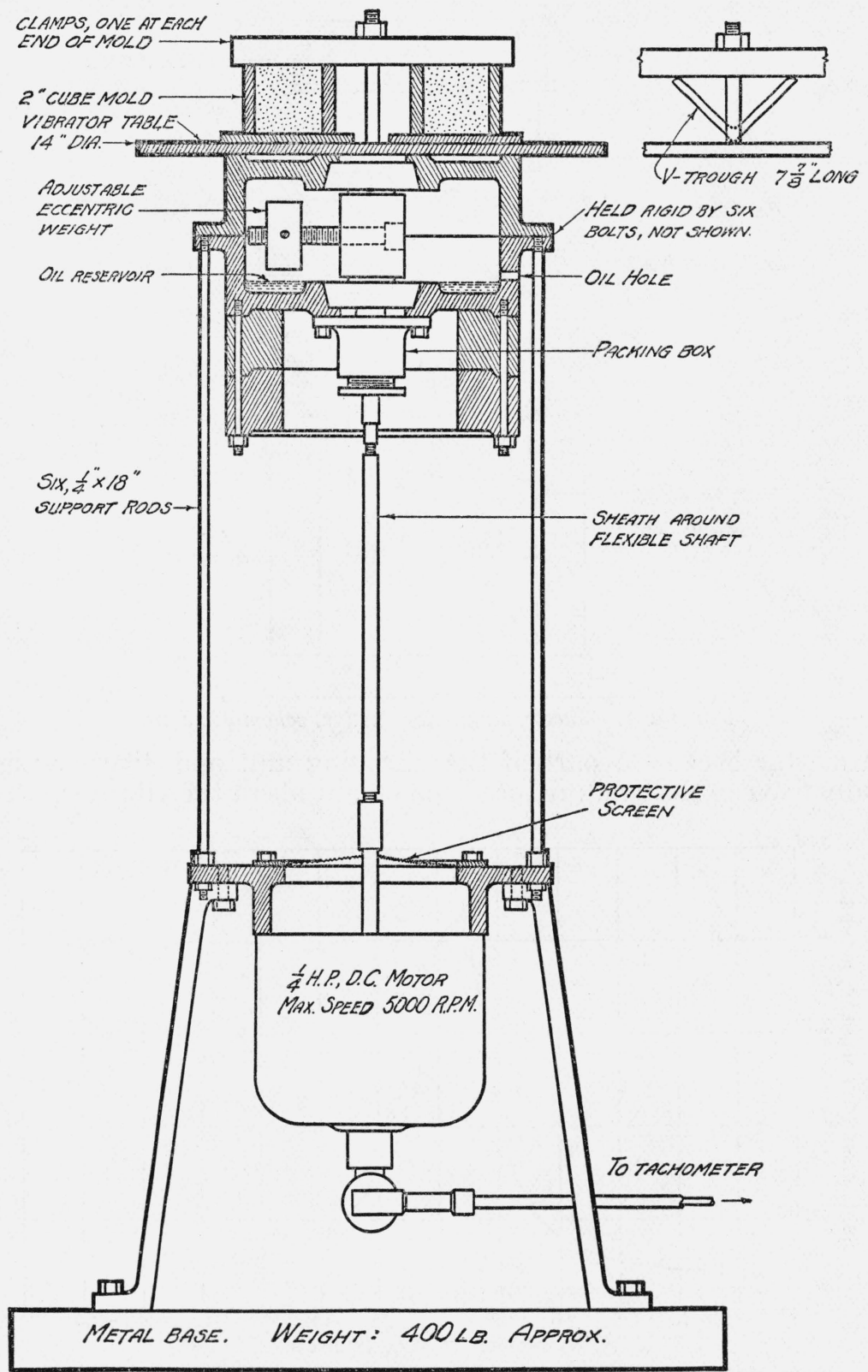

FigURe 3.-Rotary vibrator, schematic view.

diameter vertical steel rods 18 in. long. A variable-speed electric motor rotated by a flexible shaft an eccentric weight in the horizontal plane which passed through the center of gravity of the vibrating 
table. The vibrator could be brought to its full speed of $83 \mathrm{c} / \mathrm{s}$ within 4 sec. The table with molds attached weighed about $120 \mathrm{lb}$.

The speed of rotation or frequency was controlled by resistance in the motor circuit, and the amplitude ${ }^{1}$ was varied by using eccentric weights of different masses and also by adjusting their distance from the center of the rotating shaft. The motor speed was measured by means of a centrifugal type tachometer. The amplitude of the vibrator was approximately as computed theoretically from the relative mass of the eccentric weights, their eccentricity, and the total weight of table and molds, including eccentric weights. With the mortar compacted in the molds, the additional weight of the mortar theoretically reduced the amplitude 3 per cent; and this was found to be approximately correct, although it was difficult to measure the amplitude of the rotary vibrator because of the slight swinging of the table at its natural frequency.

The amplitude was constant within the range of speeds used. This system had two fundamental modes of low frequency - one a torsional mode with a period of about one-third second, about the axis of vibration, the other a flexural mode resulting in a circular motion of the same nature as the induced vibration but far larger in amplitude, having a period of about 1 second.

The amplitudes of both vibrators were measured with a micrometer microscope viewing an illuminated cross hair which was fixed on the vibrating unit. The measurements of amplitude are believed to be accurate to 0.0005 in. or better.

\section{MATERIALS AND SPECIMENS}

The portland cement used met the requirements of Federal Specification SS-C-191a. The cement was thoroughly mixed and then stored in airtight containers until batches were weighed out for mixing. As aggregates, standard Ottawa sand ${ }^{2}$ (No. 20-30), fine (Ottawa) testing sand, ${ }^{2}$ potters' flint, fine Potomac River sand, and No. 4 to $3 / 8$ in. Potomac River gravel, largely quartz, were used. The flint was approximately 98 percent finer than $40 \mu$ and had a specific surface of $3,400 \mathrm{~cm}^{2} / \mathrm{g}$. The Potomac River sand had a fineness modulus of 2.45 .

Mortars were mixed as prescribed in Federal Specification SS-C158, paragraph $\mathrm{F}-4 \mathrm{~m}(2)$, with batches of such size that there was sufficient mortar to fill two three-gang molds. Two methods of placing the mortar in the molds were employed. In one method the molds were vibrated as they were being filled in three approximately equal layers, requiring about $1 \mathrm{~min}$. After the molds were filled, vibration was continued for another minute. In the second method, the molds were filled to heaping, the vibrator started, and the molds were vibrated for $60 \mathrm{sec}$ from the time the testing speed was attained. After the vibration period, the mortar above the tops of molds was cut off with a sawing motion of the straight edge of a trowel held at an angle of about $45^{\circ}$ from the horizontal. No other troweling or smoothing was employed. Specimens were stored in the damp closet for $20 \mathrm{hr}$ at $70^{\circ} \pm 2^{\circ} \mathrm{F}$ and relative humidity of 95 percent or higher. They were then stored in water at $70^{\circ} \pm 2^{\circ} \mathrm{F}$ until tested in compression.

\footnotetext{
${ }^{1}$ Amplitude is the maximum displacement from position of rest. The total excursion of the head is twice the amplitude.

2 Federal Specification SS-C-158.
} 
The comparison group of hand-compacted cubes was fabricated according to the method prescribed in Federal Specification SS-C-158.

The cubes upon which the air voids were determined were removed from the molds at the end of $20 \mathrm{hr}$ and weighed. The water, cement, and aggregate were assumed to be present in the proportions as mixed, and their total bulk was computed. The difference between this value and the bulk of the 2 -in. cube $\left(8\right.$ in. $\left.^{3}\right)$ was tabulated as the air voids. Thus, voids caused by any irregularity in the top of the cube (fig. 4) were included in the computed air voids.

The 6- by 12-in. concrete cylinders were proportioned 1:2.2:3.8, by weight, of cement, Potomac River sand, and No. 4 to $1 \frac{1}{2}$ in. Potomac River gravel. Three cylinders were made with $C / W$ ratio of 1.7 and three with a $C / W$ ratio of 2.0 . The cylinders were rodded by the usual ASTM method. They were kept in the damp storage until test.

Compression tests of all specimens were made at the age of 7 days. In the testing of all cubes the load was applied at the rate of 6,000 pounds per square inch per minute; in the testing of concrete cylinders the load was applied at the rate of 500 pounds per square inch per minute.

\section{TESTS}

\section{MOVEMENT OF MORTAR IN MOLD (ROTARY VIBRATOR)}

Studies were made of the motion of the mortar during vibration by using black and white mortars placed in definite patterns in the mold and also by measuring the rotation of the mortar within the molds during vibration.

\section{(a) STUDY OF MOVEMENT BY STRATIFIED MORTARS}

During vibration on the rotary vibrator, the mortar continuously rotated about the vertical axis of the mold. A study was therefore made to determine whether this movement had any undesirable features. The vibrator was operated at a speed of $40 \mathrm{c} / \mathrm{s}$ with an amplitude of 0.03 in. A white portland cement standard Ottawa sand mortar (proportions 1:3.5 by weight) with varying percentages of mixing water, and the same mortar colored by carbon black were placed in the molds in strata and were vibrated a short time to determine if segregation occurred other than that which could be observed on the tops of the cubes. At the end of $24 \mathrm{hr}$ the cubes were removed from the molds and split open. Figure 5 shows a group of four such cubes of mortars with 10 percent of mixing water. The two broken halves of each of the four cubes are shown. In the upper left cube, white mortar was placed in the lower half, black in the upper half. In the upper right cube, a vertical cylinder of black mortar was placed in the surrounding white mortar. The mortar in the lower two cubes was placed in two parts, white on the front left side, black in the rear right side. The motion of the mortar was upward in the center of the mold and downward at the sides, as can be seen in the two upper cubes. The upper portion of the mortar had rotated through a greater angle than had the mortar at the bottom of the mold, as shown by the two cubes at the bottom of the figure.

The motion is largely laminar, the turbulence or intermixing of the mortars of different color being small in dimension. Neither in the mortars shown in figure 5 nor in the other drier mortars was there any evidence of segregation of cement or of water. If the mortar 


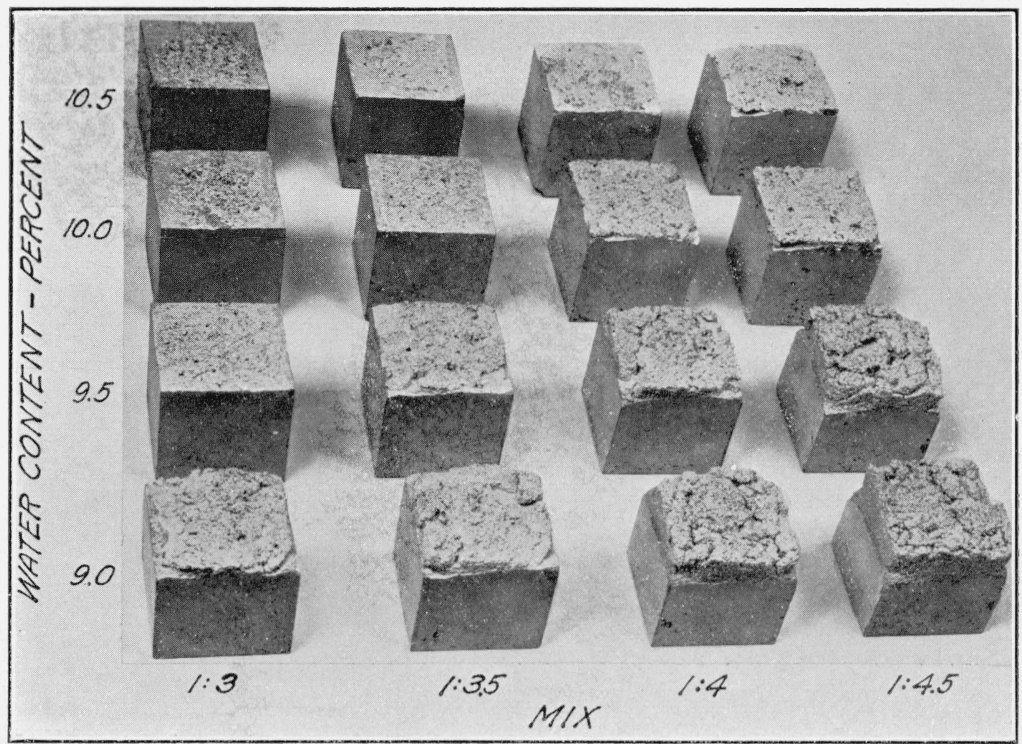

Figure 4.-Extent of compaction as shown by condition of mortar in cubes.

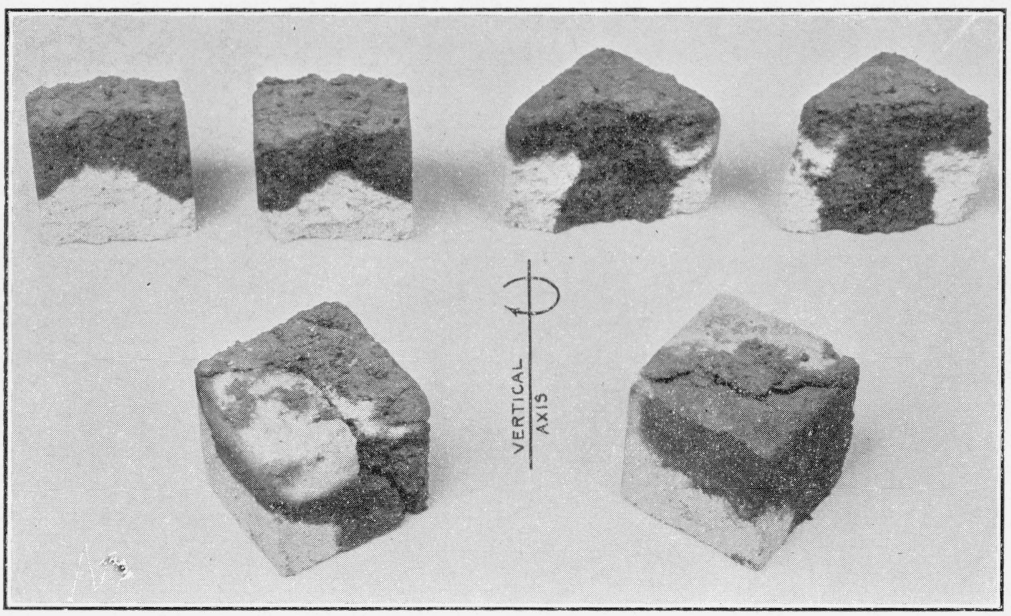

FIGURE 5.-Cubes of colored mortars showing the movement of mortar caused. by vibration. 
was too dry, containing say in the proximity of 8 percent of mixing water, the molds were not filled, the mortar first forming into approximately a 2-in. diameter cylinder, with axis vertical, after which the corners of the mold commenced filling. In the mixes with more water (9 percent or greater) the corners of the molds were always filled as the mortar rotated. The movements of the mortar were greater with the drier mixes.

\section{(b) STUDY OF ROTATION OF MORTARS}

The movement of the mortars in the molds on the rotary vibrator was also studied by measurement of the rotation by means of metal can covers about $2 \mathrm{in}$. in diameter through which four wire brads were driven with the heads firmly soldered in place. The brads were placed equidistant from the center of the cover and equally spaced on the circumference. Various length brads from $3 / \%$ in. to $1 \frac{1}{2}$ in. were used. The 1-in. brads appeared to be the most satisfactory. The covers with short brads rotated more than those with long brads, indicating as with the varicolored mortars that the mortar on top rotated more than that at the bottom of the mold.

In measuring the angle of rotation, the molds were first filled with mortar and the covers were then placed in contact with the upper surface of the cube with the brads in the mortar. The cube molds were then vibrated for $1 \mathrm{~min}$, and the angle of rotation of the covers was measured. The rate of rotation of the cover was initially rapid. It decreased gradually and approached a constant value, until after a certain time the rate of rotation was quite constant. The initial rate varied as did the time required to assume a constant rate, depending upon the richness and wetness of the mortar. Since the rate of rotation of all mortars was approximately the same after the rate became constant, it could not be used to differentiate between mortars of varying consistency.

A series of tests was made using one batch of each of the standard Ottawa sand mortars with water contents of $9,9 \frac{1}{2}, 10$, and $10 \frac{1}{2}$ percent. The mortars were compacted for $1 \mathrm{~min}$ on the rotary vibrator at $40 \mathrm{c} / \mathrm{s}$ and 0.030 -in. amplitude. The rotation of the can covers during the first minute is plotted on a logarithmic scale against the $C / W$ ratio in figure 6 . This leads to a family of approximately straight lines independent of the cement-sand ratios. Dotted lines connect mortars with the same percentage of water.

The values shown in figure 6 are averages of six measurements on one batch, it being desirable to have at least that number of measurements to secure a sufficiently reliable value. Although conceivably such an average value would give some indication of the consistency of the mortar, the method was considered too tedious and subject to too great an experimental error for use as a routine test method.

\section{FLOW OF MORTARS ON FLOW TABLE AND ON VIBRATORS}

\section{(a) FLOW ON A FLAT PLATE}

The diameters of mortar specimens were measured at intervals of five drops of the flow table. ${ }^{3}$ The increase in diameter from the original diameter at each number of drops has been termed the "flow" for that number of drops. The data are given in figure 7. As may be

\footnotetext{
${ }^{3}$ Federal Specification SS-C-158.
} 
seen from this figure, the different curves for the dry standard Ottawa sand mortar have greatly varied shapes and do not arrange themselves in a simple sequence. This is in decided contrast to the similar shapes and regular sequences of the corresponding curves for the fine testing sand mortars of wetter consistency. It can be seen that for each cement-sand ratio these curves are arranged in order of increasing water content and also that for each water content the curves are arranged in order of increasing richness of cement.

The ogee form or change in curvature of the curves at the right of figure 7 is ascribed in general to the breaking or splitting of the mortar

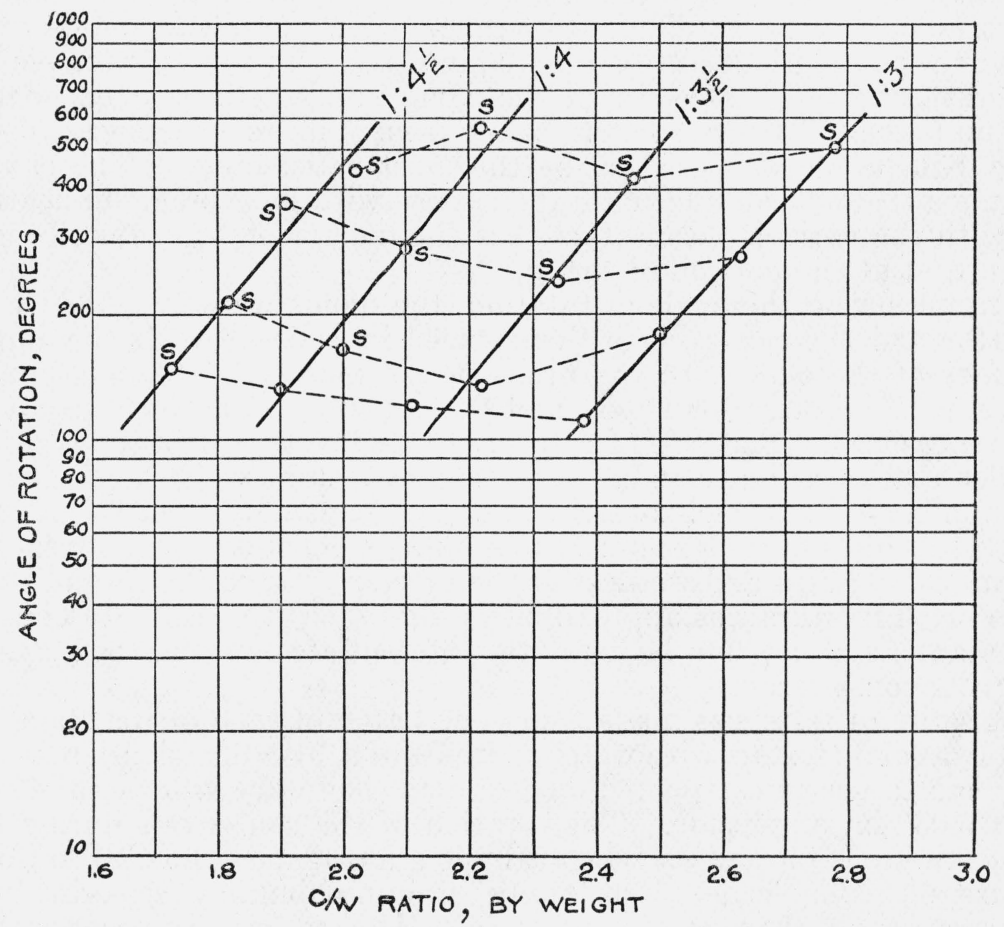

Figure 6.-Relation between angle of rotation during the first minute vibration and $C / W$ ratios.

The points marked $S$ indicate mixes whose cubes in figure 4 showed incomplete compaction.

into two or more parts by reason of its dryness and the rapid spread of the parts which are no longer mutually restrained when the splitting occurs.

The diameters of standard Ottawa sand mortar specimens were measured at intervals of $5 \mathrm{sec}$ during vibration on a flat plate on both the magnetic and rotary vibrators. The hollow truncated cone used with the 10-in. flow table was placed on the flat plate fastened to the motionless vibrator and was filled with mortar in the standard manner to form the mortar specimens. The increase in diameter of the mortar specimens at any time was termed the "flow" for that duration of vibration.

The flow of mortars on the flat plate fastened to the rotary vibrator has several undesirable characteristics. The mortar upon start of 
vibration does not immediately flow but slips about on the plate for an indefinite short period, after which flow starts. When the mortar begins to flow it loses its circular perimeter, the outer edge assuming very irregular shapes. The curves of the flow of this mortar with time are intermediate in their regularity between the two groups

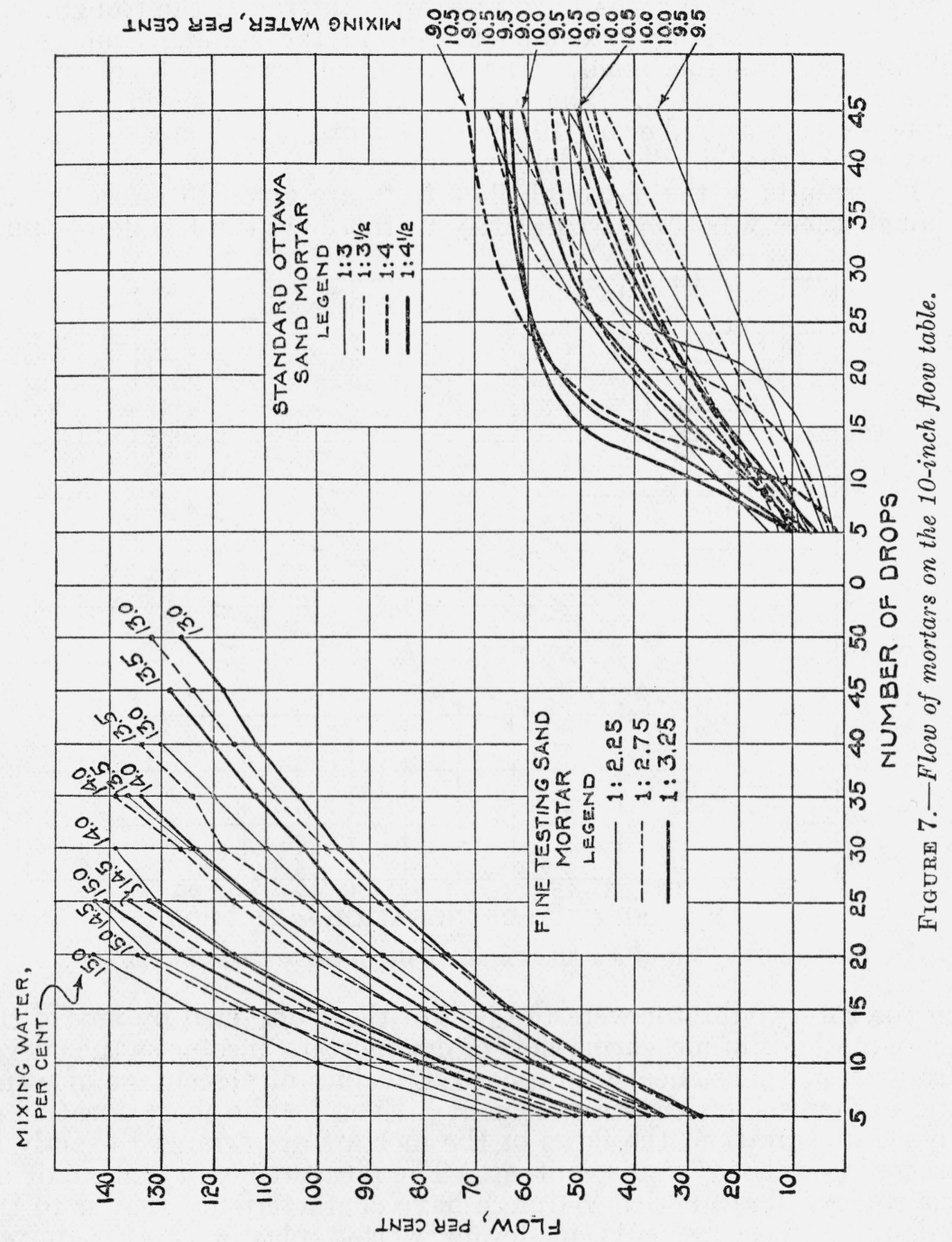

shown in figure 7. For these reasons this test method is not recommended.

The flow of standard Ottawa sand mortars on the magnetic vibrator, flat plate, is shown in figure 8 . These curves are in nearly as definite a sequence as those for the fine testing sand mortars on the flow table, shown at the left in figure 7. 
(b) FLOW IN ATV-TROUGH

The flows of mortar were also determined in a V-trough made of structural-steel angle attached to the vibrators, as illustrated in figure 3. The mortar was placed in the trough in the space between two vertical plates 2 in. apart and perpendicular to the axis of the trough. The mortar was filled flush with the top of the trough, with just enough working to compact it as in the standard method of filling the flow-table mold. The vertical plates were then removed and vibration started. The length of the mortar specimen in the trough was measured every $10 \mathrm{sec}$ for $1 \mathrm{~min}$. The increase in length was termed the "flow" for each time interval.

The results of the $V$-trough flow tests are given in figure 9. Although there was some irregularity in the flow, the results obtained

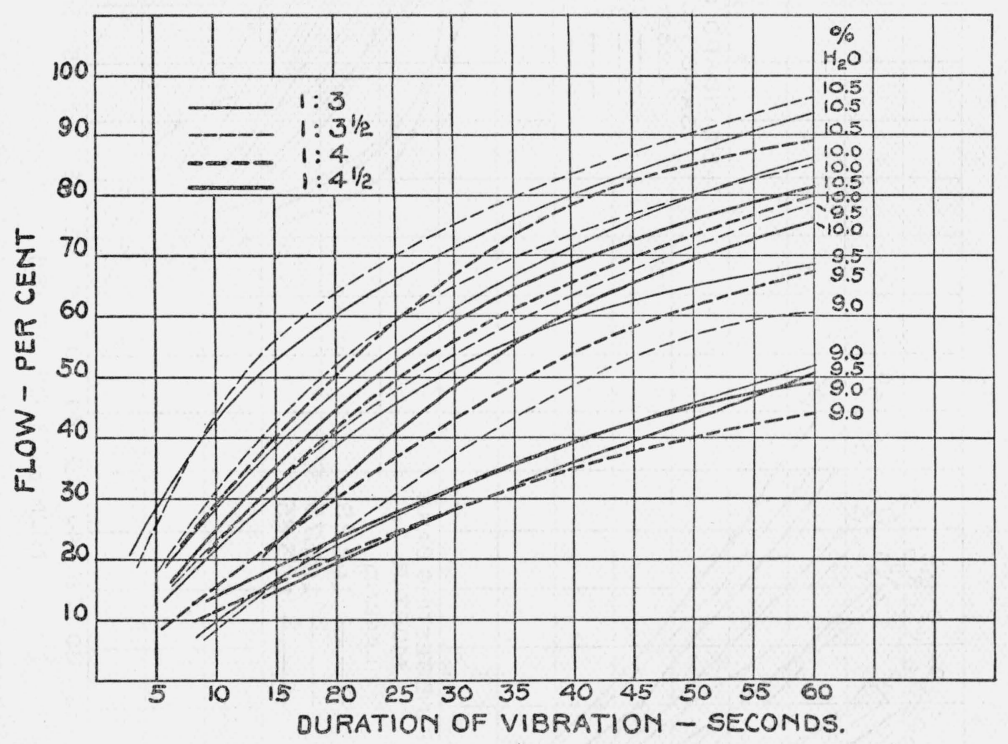

FIGURE 8.-Flow of mortars on flat plate on electromagnetic vibrator.

on the rotary vibrator were the best of those obtained by any of the three methods of measuring flow of dry mortars, insofar as the curves are arranged most nearly in ascending values of percentage of water and in increasing richness of cement. Even for the short duration of 20 sec of vibration, the flows of the mortars are arranged exactly in ascending order of water content. The measurements thus made on the rotary vibrator with $\mathrm{V}$-trough have characteristics similar to the flow-table measurements made on wetter plastic mortar mixes, intended for hand compaction, such as those described in Federal Specification SS-C-158.

From the few studies made of like batches, it appeared that the reproducibility of mortar flows in the $V$-trough, rotary vibrator, was approximately the same as that of $1: 2.75$ fine testing sand mortars with a flow of 100 to 115 (25 drops), as made on the standard 10-in. flow table. (See fig. 7.)

The flow curves for the mortars in the V-trough on the magnetic vibrator gave fairly good results but were not arranged in as definite a 
sequence as for the flat plate on the same vibrator, or in the V-trough on the rotary vibrator.

The tests show that the $\mathrm{V}$-trough on the rotary vibrator, or the flat plate on the magnetic vibrator may be used to measure the consistency in mortars of the dryness required for compaction by vibration. Measurements on vibrators may thus be used for dry mortars in place of the standard 10-in. flow table, which is suitable only for the wetter or plastic mortars.

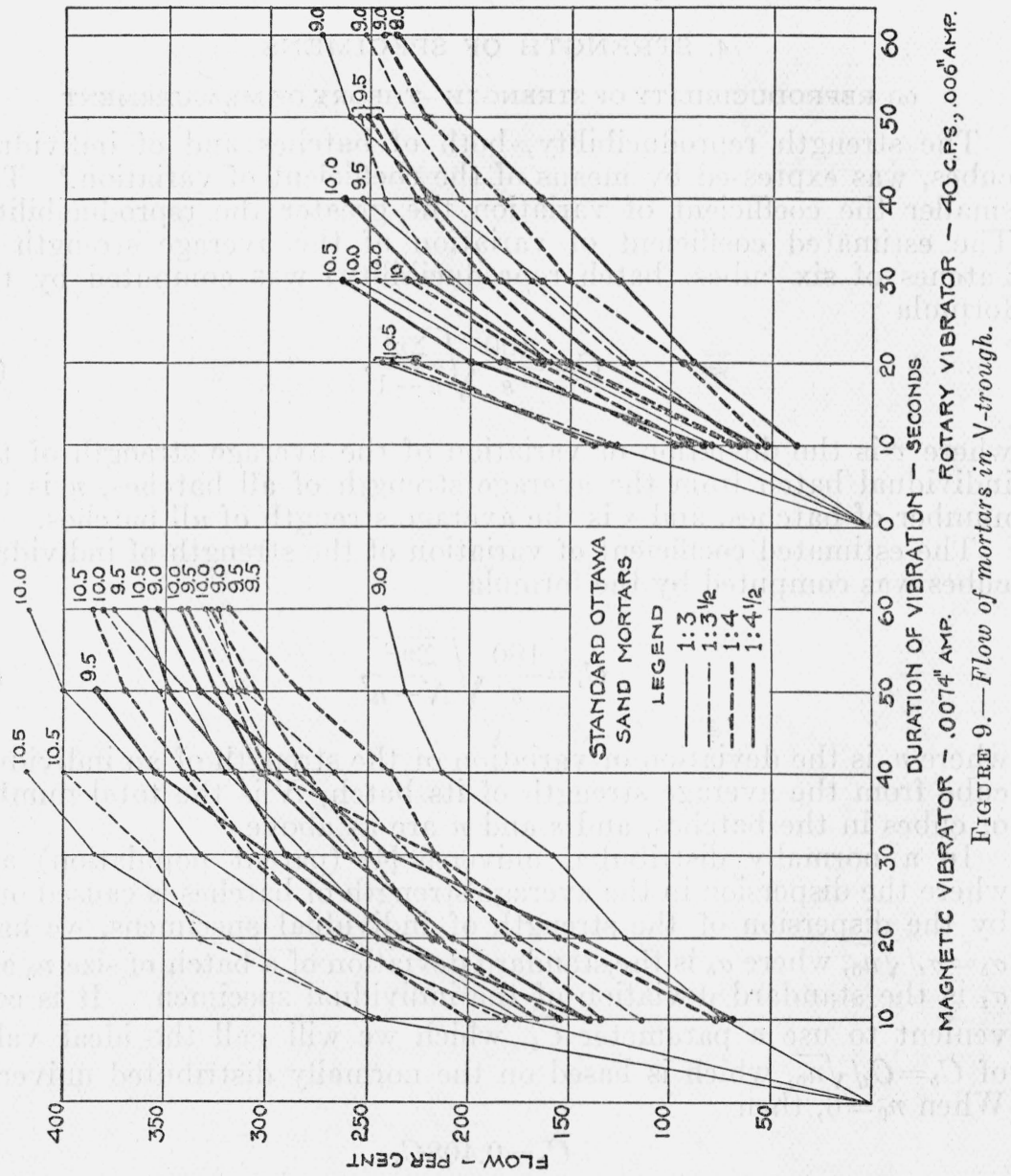

3. NONHOMOGENEOUS COMPACTION OF MORTARS

The strengths and solidities of the cubes are not wholly adequate criteria for determining the degree of the compaction. In some mixes compacted by vibration the compaction was not homogeneous throughout the cube, although the body of the cube was compact and strong. An upper layer of incompletely compacted mortar was present in the upper portion of the cube. This is illustrated in figure 4 for cubes of cement and standard sand in different proportions and with differ- 
ent amounts of water. The specimens were vibrated for $1 \mathrm{~min}$. on the rotary vibrator, $40 \mathrm{c} / \mathrm{s}, 0.031$-in. amplitude.

The specimens in the diagonal row from lower left to upper right were almost completely compacted throughout to an equal degree, as visually estimated. The compaction of the cubes became increasingly poor and nonhomogeneous in passing below the foregoing diagonal. This was accompanied by an increase in the amount of incompletely compacted mortar on top of the cubes. The compaction of all cubes above the diagonal was practically perfect.

\section{STRENGTH OF SPECIMENS}

(a) REPRODUCIBILITY OF STRENGTH-THEORY OF MEASUREMENT

The strength reproducibility, both of batches and of individual cubes, was expressed by means of the coefficient of variation. ${ }^{4}$ The smaller the coefficient of variation the greater the reproducibility. The estimated coefficient of variation of the average strength of batches of six cubes (batch reproducibility) was computed by the formula

$$
C_{b}=\frac{100}{s} \sqrt{\frac{\Sigma v^{2}}{n-1}}
$$

where $v$ is the deviation or variation of the average strength of the individual batch from the average strength of all batches, $n$ is the number of batches, and $s$ is the average strength of all batches.

The estimated coefficient of variation of the strength of individual cubes was computed by the formula

$$
C_{i}=\frac{100}{s} \sqrt{\frac{\Sigma v_{i}^{2}}{N-n}},
$$

where $v_{i}$ is the deviation or variation of the strength of an individual cube from the average strength of its batch, $N$ is the total number of cubes in the batches, and $s$ and $n$ are as above.

In a normally distributed universe [4] (parent population) and where the dispersion in the average strength of batches is caused only by the dispersion of the strength of individual specimens, we have $\sigma_{b}=\sigma_{t} / \sqrt{n_{0}}$, where $\sigma_{b}$ is the standard deviation of a batch of size $n_{0}$ and $\sigma_{i}$ is the standard deviation of the individual specimen. It is convenient to use a parameter $\bar{C}_{b}$, which we will call the ideal value of $C_{b}=C_{i} / \sqrt{n_{0}}$, which is based on the normally distributed universe. When $n_{0}=6$, then

$$
\bar{C}_{b}=0.408 C_{i}
$$

\section{(b) HAND-COMPACTED SPECIMENS}

The compressive strength of a 1:2.2:3.8 (by weight) concrete was determined from 6- by 12-in. test cylinders. Two water contents were used; the $C / W$ ratios were 1.71 and 2.00 , the concretes had flows (fifteen $1 / 8$-in. drops on the 30 -in. flow table) of 25 and 8 , slumps of $13 / 4$ and $1 / 4$ in., and 7-day strengths of 2,825 and $3,250 \mathrm{lb} / \mathrm{in} .{ }^{2}$, respectively.

\footnotetext{
- The coefficient of variation is the standard deviation expressed in percentage of the mean value.
} 
A number of cubes were made in accordance with the requirements of Federal Specification SS-C-158, proportions 1:2.75, cement to fine testing sand, by weight, with just enough mixing water to give a flow of 100 . The cubes were made by four operators each of whom made one batch of six cubes a day. The test results are given in table 1. The average strength of the cubes was $2,900 \mathrm{lb} / \mathrm{in}^{2}{ }^{2}$, equal to the strength of the 1:2.2:3.8 concrete with a water content corresponding to approximately $C / W=1.7$. The average coefficient of variation of the strength of batches $\left(C_{b}\right)$ is 3.8. This is the day-by-day variation in the strength obtained by the four operators.

TABLE 1.-Data on hand-compacted plastic mortar cubes (fabricated by method of Federal Specification SS-C-158)

\begin{tabular}{|c|c|c|c|c|}
\hline \multirow{2}{*}{ Operator 1} & \multirow{2}{*}{$\begin{array}{l}\text { Mean com- } \\
\text { pressive } \\
\text { strength }\end{array}$} & \multicolumn{2}{|c|}{ Coefficient of variation } & \multirow{2}{*}{ Voids } \\
\hline & & $C_{b}$ & $C_{i}$ & \\
\hline $\begin{array}{l}A \\
B\end{array}$ & $\begin{array}{r}\text { lb/in.2 } \\
2,850 \\
2,900 \\
2,900 \\
2,940 \\
\end{array}$ & $\begin{array}{l}0.9 \\
4.4 \\
4.4 \\
4.5\end{array}$ & \begin{tabular}{l|}
3.3 \\
3.7 \\
4.1 \\
2.8 \\
\end{tabular} & 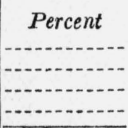 \\
\hline Weighted mean & 2,900 & 3.8 & 3.5 & 7.3 \\
\hline
\end{tabular}

1 Operator $A$ made 3 groups of 6 cubes; operators $B, C$, and $D$ made 6 groups of 6 cubes. Each operator made but 1 group on any one day. Specimens tested at 7 days.

It is of interest to note that the variation between batches is not attributable to the scatter in the strength of individual cubes. If the scatter in the batch strength were due to the scatter in the strength of the individual cubes, the coefficient of variation of the batch strength $\left(\bar{C}_{b}\right)$ would be, from eq $3,0.408 C_{i}$ or $0.408 \times 3.5=1.4$. The average $C_{b}$ from table 1 is 3.8 , almost three times this value, indicating a dayby-day or batch-to-batch variation much greater than that caused by the scatter in the strengths of individual cubes in a batch.

It may be noted that the average strengths obtained by the several operators are in remarkable agreement. Statistical analysis shows that the variation in the strengths obtained by the different operators is no greater than the variation which would be expected if one operator had made all the specimens.

\section{(c) MORTAR SPECIMENS COMPACTED BY VIBRATION}

(1) Study of different aggregates and proportions.-Preliminary studies of compaction by vibration were made on mortars of various proportions, with various combinations of the aggregates, and vibrated for varying durations and with various amplitudes and frequencies of vibration. Tables 2, 3, and 4 summarize the results of these tests. The mixes of table 2 were compacted by the rotary vibrator; the three "pebble" mixes of table 3 were compacted under two accelerations each for the rotary and for the magnetic vibrator. The mixes of table 4 were compacted on the rotary vibrator with an amplitude of $0.007 \mathrm{in}$. and frequencies of 33 to $83 \mathrm{c} / \mathrm{s}$.

From table 2 it is immediately apparent that, with the exception of one of the three mixes containing potter's flint, the strengths were considerably above the strength of $2,900 \mathrm{lb} / \mathrm{in} .{ }^{2}$ of the hand-fabricated plastic mortar cubes, and that with the mixes containing gravel much higher strengths could be obtained. 
TABLE 2.-Data on mortars with several aggregates in varying proportions

[Compacted on rotary vibrator, $83 \mathrm{c} / \mathrm{s}, 0.007$-in. amplitude. Molds first filled, then vibrated]

\begin{tabular}{|c|c|c|c|c|c|c|c|c|}
\hline \multicolumn{6}{|c|}{ Proportions, parts by weight } & \multirow{2}{*}{$\begin{array}{c}\text { Cement// } \\
\text { water } \\
\text { ratio, } \\
\text { by } \\
\text { weight }\end{array}$} & \multirow[b]{2}{*}{$\begin{array}{l}\text { Compres- } \\
\text { sive } \\
\text { strength o }\end{array}$} & \multirow[b]{2}{*}{$\begin{array}{c}\text { Coeffi- } \\
\text { cient of } \\
\text { variation, } \\
C_{i}\end{array}$} \\
\hline Cement & $\begin{array}{c}\text { Potter's } \\
\text { flint }\end{array}$ & $\begin{array}{l}\text { Fine } \\
\text { testing } \\
\text { sand }\end{array}$ & $\begin{array}{c}\text { Standard } \\
\text { Ottawa } \\
\text { sand }\end{array}$ & $\begin{array}{c}\text { Gravel } \\
\text { No. } 4 \text { to } \\
3 / 8 \text { in. }\end{array}$ & $\begin{array}{l}\text { Water, } \\
\text { percent- } \\
\text { age by } \\
\text { weight, } \\
\text { dry mix }\end{array}$ & & & \\
\hline $\begin{array}{r}0.6 \\
.7 \\
.8 \\
1.0\end{array}$ & $\begin{array}{r}0.4 \\
.3 \\
.2 \\
0\end{array}$ & $\begin{array}{l}0 \\
0 \\
0 \\
0\end{array}$ & $\begin{array}{l}3 \\
3 \\
3 \\
3\end{array}$ & $\begin{array}{l}0 \\
0 \\
0 \\
0\end{array}$ & $\begin{array}{r}10.0 \\
10.0 \\
10.0 \\
9.5\end{array}$ & $\begin{array}{l}1.50 \\
1.75 \\
2.00 \\
2.63\end{array}$ & $\begin{array}{l}\text { lb/in. }{ }^{2} \\
2,000 \\
3,520 \\
5,150 \\
4,800\end{array}$ & $\begin{array}{l}2.8 \\
2.3 \\
2.6 \\
1.8\end{array}$ \\
\hline $\begin{array}{l}1 \\
1 \\
1 \\
1\end{array}$ & $\begin{array}{l}0 \\
0 \\
0 \\
0\end{array}$ & $\begin{array}{l}0 \\
0 \\
0.5 \\
1.0\end{array}$ & $\begin{array}{l}3.25 \\
3.5 \\
3 \\
2.5\end{array}$ & $\begin{array}{l}0 \\
0 \\
0 \\
0\end{array}$ & $\begin{array}{r}9.5 \\
9.5 \\
10.0 \\
10.0\end{array}$ & $\begin{array}{l}2.48 \\
2.33 \\
2.35 \\
2.22\end{array}$ & $\begin{array}{l}4,260 \\
3,480 \\
3,700 \\
3,960\end{array}$ & $\begin{array}{l}2.1 \\
0.9 \\
4.0 \\
1.9\end{array}$ \\
\hline $\begin{array}{l}1 \\
1 \\
1 \\
1\end{array}$ & $\begin{array}{l}0 \\
0 \\
0 \\
0\end{array}$ & $\begin{array}{l}1.0 \\
1.0 \\
1.5 \\
2.0\end{array}$ & $\begin{array}{l}2.5 \\
2.5 \\
2.0 \\
1.5\end{array}$ & $\begin{array}{l}0 \\
0 \\
0 \\
0\end{array}$ & $\begin{array}{l}10.0 \\
10.0 \\
10.0 \\
10.0\end{array}$ & $\begin{array}{l}2.22 \\
2.22 \\
2.22 \\
2.22\end{array}$ & $\begin{array}{l}3,730 \\
3,600 \\
3,970 \\
4,250\end{array}$ & $\begin{array}{l}2.4 \\
2.1 \\
2.2 \\
1.9\end{array}$ \\
\hline $\begin{array}{l}1 \\
1 \\
1 \\
1\end{array}$ & $\begin{array}{l}0 \\
0 \\
0 \\
0\end{array}$ & $\begin{array}{l}2.0 \\
2.0 \\
2.5 \\
3.0\end{array}$ & $\begin{array}{l}1.5 \\
1.5 \\
1.0 \\
0.5\end{array}$ & $\begin{array}{l}0 \\
0 \\
0 \\
0\end{array}$ & $\begin{array}{l}10.0 \\
10.0 \\
10.0 \\
10.0\end{array}$ & $\begin{array}{l}2.22 \\
2.22 \\
2.22 \\
2.22\end{array}$ & $\begin{array}{l}4,030 \\
3,640 \\
4,160 \\
4,390\end{array}$ & $\begin{array}{l}1.4 \\
1.9 \\
1.7 \\
1.6\end{array}$ \\
\hline $\begin{array}{l}1 \\
1 \\
1 \\
1\end{array}$ & $\begin{array}{l}0 \\
0 \\
0 \\
0\end{array}$ & $\begin{array}{l}0 \\
0 \\
0 \\
0\end{array}$ & $\begin{array}{l}2.0 \\
2.0 \\
2.0 \\
2.5\end{array}$ & $\begin{array}{l}2.0 \\
2.5 \\
3.0 \\
2.5\end{array}$ & $\begin{array}{l}8.0 \\
7.55 \\
7.15 \\
7.6\end{array}$ & $\begin{array}{l}2.50 \\
2.41 \\
2.33 \\
2.19\end{array}$ & $\begin{array}{l}6,080 \\
6,070 \\
6,120 \\
4,580\end{array}$ & $\begin{array}{l}3.4 \\
2.7 \\
3.2 \\
2.8\end{array}$ \\
\hline $\begin{array}{l}1 \\
1 \\
1 \\
1\end{array}$ & $\begin{array}{l}0 \\
0 \\
0 \\
0\end{array}$ & $\begin{array}{l}0 \\
0 \\
0 \\
0\end{array}$ & $\begin{array}{l}2.75 \\
\text { 3. } 0 \\
\text { 3. } 25 \\
\text { 3. } 25\end{array}$ & $\begin{array}{l}2.5 \\
2.5 \\
2.5 \\
2.5\end{array}$ & $\begin{array}{l}7.6 \\
7.6 \\
6.95 \\
7.4\end{array}$ & $\begin{array}{l}2.19 \\
2.19 \\
2.14 \\
2.00\end{array}$ & $\begin{array}{l}4,450 \\
4,330 \\
4,100 \\
3,360\end{array}$ & $\begin{array}{l}2.1 \\
2.3 \\
2.2 \\
2.6\end{array}$ \\
\hline $\begin{array}{l}1 \\
1 \\
1 \\
1\end{array}$ & $\begin{array}{l}0 \\
0 \\
0 \\
0\end{array}$ & $\begin{array}{l}0 \\
0 \\
0 \\
0\end{array}$ & $\begin{array}{l}3.5 \\
3.0 \\
3.0 \\
3.5\end{array}$ & $\begin{array}{l}2.5 \\
2.5 \\
3.0 \\
3.0\end{array}$ & $\begin{array}{l}6.7 \\
7.15 \\
7.15 \\
6.67\end{array}$ & $\begin{array}{l}2.14 \\
2.00 \\
2.00 \\
2.00\end{array}$ & $\begin{array}{l}3,920 \\
4,400 \\
3,600 \\
3,570\end{array}$ & $\begin{array}{l}2.6 \\
3.1 \\
3.4 \\
3.6\end{array}$ \\
\hline
\end{tabular}

a Specimens tested at 7 days.

Each line represents tests of 18 cubes.

TABLE 3.-Data on three "pebble" mortars a compacted by vibration

Each strength given is the average of 6 batches of 6 cubes, tested at the age of 7 days. Molds filled, then vibrated]

\begin{tabular}{|c|c|c|c|c|c|c|c|c|c|c|c|}
\hline \multirow{3}{*}{ Vibrator } & \multirow{3}{*}{$\begin{array}{c}\text { Accel- } \\
\text { era- } \\
\text { tion, } \\
g\end{array}$} & \multirow{3}{*}{$\begin{array}{l}\text { Dura- } \\
\text { tion }\end{array}$} & \multicolumn{3}{|c|}{ Bates mix } & \multicolumn{3}{|c|}{ Bates mix modified } & \multicolumn{3}{|c|}{ Pearson mix modified } \\
\hline & & & \multirow{2}{*}{$\begin{array}{c}\text { Com- } \\
\text { pressive } \\
\text { strength }\end{array}$} & \multicolumn{2}{|c|}{$\begin{array}{l}\text { Coefficient } \\
\text { of variation }\end{array}$} & \multirow{2}{*}{$\begin{array}{l}\text { Com- } \\
\text { pressive } \\
\text { strength }\end{array}$} & \multicolumn{2}{|c|}{$\begin{array}{l}\text { Coefficient } \\
\text { of variation }\end{array}$} & \multirow{2}{*}{$\begin{array}{l}\text { Com- } \\
\text { pressive } \\
\text { strength }\end{array}$} & \multicolumn{2}{|c|}{$\begin{array}{l}\text { Coefficient } \\
\text { of variation }\end{array}$} \\
\hline & & & & $C_{b}$ & $C_{i}$ & & $C_{b}$ & $C_{i}$ & & $C_{b}$ & $C_{i}$ \\
\hline \multirow[t]{2}{*}{$\begin{array}{l}\text { Magnetic.... } \\
\text { Do } \\
\text { Do } \\
\text { Do } \\
\text { Do } \\
\text { Do } \\
\text { Mean }\end{array}$} & \multirow[t]{2}{*}{$\begin{array}{l}\text { b } 7.3 \\
\text { b } 7.3 \\
\text { b } 7.3 \\
\text { c } 16.5 \\
\text { c } 16.5 \\
\text { c } 16.5\end{array}$} & $\begin{array}{r}\text { Seconds } \\
30 \\
60 \\
90 \\
30 \\
60 \\
90 \\
\end{array}$ & $\begin{array}{r}l b / i n .^{2} \\
4,330 \\
4,420 \\
4,370 \\
4,410 \\
4,550 \\
4,550 \\
\end{array}$ & $\begin{array}{l}2.9 \\
2.0 \\
1.9 \\
2.9 \\
4.0 \\
3.0 \\
\end{array}$ & $\begin{array}{l}2.6 \\
2.5 \\
2.5 \\
2.7 \\
3.2 \\
3.1 \\
\end{array}$ & $\begin{array}{r}l b / \text { in }^{2} \\
4,920 \\
4,780 \\
4,800 \\
5,000 \\
4,980 \\
5,080 \\
\end{array}$ & $\begin{array}{l}3.6 \\
3.3 \\
4.0 \\
3.1 \\
3.5 \\
3.2 \\
\end{array}$ & $\begin{array}{l}2.6 \\
2.4 \\
3.0 \\
3.7 \\
3.7 \\
3.1 \\
\end{array}$ & $\begin{array}{l}l b / \text { in }^{2} \\
3,720 \\
3,700 \\
3,750 \\
4,110 \\
4,140 \\
4,260 \\
\end{array}$ & $\begin{array}{l}4.0 \\
1.3 \\
2.5 \\
4.6 \\
4.6\end{array}$ & $\begin{array}{l}3.9 \\
2.7 \\
3.0 \\
3.6 \\
3.3 \\
3.3 \\
\end{array}$ \\
\hline & & - & 4,420 & 2.8 & 2.8 & 4,920 & 3.4 & 3.1 & 3,950 & 3.7 & 3.2 \\
\hline \multirow[t]{2}{*}{$\begin{array}{l}\text { Rotary } \\
\text { Do } \\
\text { Do } \\
\text { Do } \\
\text { Do } \\
\text { Do }\end{array}$} & \multirow[t]{2}{*}{$\begin{array}{r}\text { d } 4.2 \\
\text { d } 4.2 \\
\text { d } 4.2 \\
\text { e } 10.5 \\
\text { e } 10.5 \\
\text { e } 10.5\end{array}$} & $\begin{array}{l}30 \\
60 \\
90 \\
30 \\
60 \\
90 \\
\end{array}$ & $\begin{array}{l}4,360 \\
4,420 \\
4,480 \\
4,490 \\
4,610 \\
4,640 \\
\end{array}$ & $\begin{array}{l}1.0 \\
1.3 \\
2.4 \\
3.5 \\
2.9 \\
2.8 \\
\end{array}$ & $\begin{array}{l}2.0 \\
2.4 \\
2.7 \\
2.4 \\
2.1 \\
2.3 \\
\end{array}$ & $\begin{array}{l}4,760 \\
4,710 \\
4,850 \\
4,980 \\
4,830 \\
4,900 \\
\end{array}$ & $\begin{array}{l}2 . \\
1 . \\
2 . \\
2 . \\
2 . \\
2 .\end{array}$ & $\begin{array}{l}1.8 \\
2.4 \\
2.5 \\
1.8 \\
2.3 \\
2.5 \\
\end{array}$ & $\begin{array}{l}3,800 \\
3,840 \\
3,820 \\
4,150 \\
4,200 \\
4,300 \\
\end{array}$ & $\begin{array}{l}4.5 \\
4.1 \\
2.1 \\
2.9 \\
\end{array}$ & $\begin{array}{l}1.8 \\
2.4 \\
2.1 \\
2.6 \\
2.2 \\
2.3 \\
\end{array}$ \\
\hline & & . & 4,500 & 2.3 & 2.3 & 4,840 & 2.1 & 2.2 & 4,020 & 4.2 & 2.2 \\
\hline
\end{tabular}

See footnotes at end of table. 
TABLE 3.-Data on three "pebble" mortars compacted by vibration-Continued MIX PROPORTIONS BY WEIGHT, IN GRAMS

\begin{tabular}{|c|c|c|c|}
\hline Component & Bates & $\begin{array}{l}\text { Bates modi- } \\
\text { fled }\end{array}$ & $\begin{array}{l}\text { Pearson mod- } \\
\text { ified }\end{array}$ \\
\hline $\begin{array}{l}\text { No. } 4 \text { to } 3 / 8 \text { in. gravel } \\
\text { Standard 20-30 Ottawa sand } \\
\text { Fine Potomac River sand }\end{array}$ & $\begin{array}{r}1,080 \\
632\end{array}$ & $\begin{array}{r}1,080 \\
540\end{array}$ & $\begin{array}{r}1,000 \\
416 \\
252\end{array}$ \\
\hline $\begin{array}{l}\text { Potters' flint } \\
\text { Cement }\end{array}$ & 88 & 108 & \\
\hline Water & 191 & 216 & 160 \\
\hline
\end{tabular}

a Based on mixes proposed for study by Committee C-1, ASTM; Proc. Am. Soc. Testing Materials 38, p. 1, 268 (1938).

b Amplitude, 0.0035 in. to 0.0065 in.; frequency, $120 \mathrm{c} / \mathrm{s}$; acceleration, 5.1 to $9.5 \mathrm{~g}$; average, $7.3 \mathrm{~g}$. Initial amplitude 0.0065 in., reducing to 0.0035 when mortars were compacted.

- Amplitude, 0.0075 in. to 0.0150 in.; frequency, $120 \mathrm{c} / \mathrm{s}$; acceleration, 11.0 to $22.0 \mathrm{~g}$; average, $16.5 \mathrm{~g}$.

d Amplitude, 0.006 in.; frequency, $83 \mathrm{c} / \mathrm{s}$; acceleration, $4.2 \mathrm{~g}$.

e Amplitude, 0.015 in.; frequency, $83 \mathrm{c} / \mathrm{s}$; acceleration, $10.5 \mathrm{~g}$.

\section{TABLE 4.-Data on effect of different speeds and durations of vibration}

Compacted on rotary vibrator; amplitude, 0.007 in. Molds first filled, then vibrated. Mortar: $1: 3.5$ standard Ottawa sand; 10 percent mixing water.]

\begin{tabular}{|c|c|c|c|c|c|c|}
\hline Speed & Duration & $\begin{array}{c}\text { Accelera- } \\
\text { tion, } g\end{array}$ & $\begin{array}{l}\text { Number of } \\
\text { specimens }\end{array}$ & Voids & $\begin{array}{l}\text { Compres- } \\
\text { sive } \\
\text { strength a }\end{array}$ & $\begin{array}{c}\text { Coefficient } \\
\text { of variation, } \\
C_{i}\end{array}$ \\
\hline $\begin{array}{l}c / s \\
33 \\
33 \\
33 \\
33\end{array}$ & $\begin{array}{c}\text { Seconds } \\
20 \\
40 \\
60 \\
90\end{array}$ & $\begin{array}{r}0.8 \\
.8 \\
.8 \\
.8\end{array}$ & $\begin{array}{r}6 \\
6 \\
18 \\
6\end{array}$ & $\begin{array}{c}\text { Percent } \\
16.7 \\
16.5 \\
16.5 \\
15.6\end{array}$ & $\begin{array}{c}l b / \text { in } .^{2} \\
2,380 \\
2,400 \\
2,390 \\
2,570\end{array}$ & $\begin{array}{l}3.4 \\
3.5 \\
4.2 \\
2.2\end{array}$ \\
\hline $\begin{array}{l}50 \\
50 \\
50 \\
50\end{array}$ & $\begin{array}{l}20 \\
40 \\
60 \\
90\end{array}$ & $\begin{array}{l}1.8 \\
1.8 \\
1.8 \\
1.8\end{array}$ & $\begin{array}{r}6 \\
6 \\
18 \\
6\end{array}$ & $\begin{array}{l}14.4 \\
13.9 \\
13.5 \\
13.1\end{array}$ & $\begin{array}{l}2,830 \\
3,030 \\
3,220 \\
3,350\end{array}$ & $\begin{array}{l}1.6 \\
1.1 \\
2.5 \\
0.9\end{array}$ \\
\hline $\begin{array}{l}67 \\
67 \\
67 \\
67\end{array}$ & $\begin{array}{l}20 \\
40 \\
60 \\
90\end{array}$ & $\begin{array}{l}3.2 \\
3.2 \\
3.2 \\
3.2\end{array}$ & $\begin{array}{r}6 \\
6 \\
18 \\
6\end{array}$ & $\begin{array}{l}13.1 \\
13.1 \\
12.7 \\
12.3\end{array}$ & $\begin{array}{l}3,350 \\
3,620 \\
3,600 \\
3,710\end{array}$ & $\begin{array}{l}2.6 \\
2.4 \\
2.1 \\
1.0\end{array}$ \\
\hline $\begin{array}{l}83 \\
83 \\
83 \\
83\end{array}$ & $\begin{array}{l}20 \\
40 \\
60 \\
90\end{array}$ & $\begin{array}{l}5.0 \\
5.0 \\
5.0 \\
5.0\end{array}$ & $\begin{array}{r}18 \\
18 \\
\text { b } 36 \\
18\end{array}$ & $\begin{array}{l}13.1 \\
13.1 \\
12.3 \\
12.3\end{array}$ & $\begin{array}{l}3,640 \\
3,750 \\
3,820 \\
3,930\end{array}$ & $\begin{array}{l}2.2 \\
1.7 \\
1.5 \\
1.7\end{array}$ \\
\hline
\end{tabular}

a Specimens tested at 7 days.

b Six cubes each by 6 operators.

The average value of $C_{i}$ for the several types of mixes is as follows: 3 series of standard sand, $1.6 ; 10$ series of standard and fine sand, 2.1 ; 3 series of flint and standard sand, $2.6 ; 12$ series of gravel, 2.8 . With two exceptions the mixes compacted by vibration had better reproducibility than the mean reproducibility of the hand-compacted specimens.

The three mixes of table 3 compacted on the rotary vibrator had in general slightly less strength dispersion than the gravel mixes of table 1 , and a greater strength dispersion than the mixes with both fine testing sand and standard Ottawa sand or with standard Ottawa sand of the same table. The mixes of table 2 were so wet that they compacted rapidly, little being gained by vibrating more than $30 \mathrm{sec}$, since cement and water splashed from the mold during vibration. The mixes were obviously too wet and should not be given much consideration.

From table 3 it is seen that the Pearson mix is sensitive to differences in the intensities of vibration from approximately 7.0 to 15.6 
$g$ in the magnetic vibrator and 4.2 to $10.5 \mathrm{~g}$ in the rotary vibrator, the "modified" Bates mix shows a slight difference, and the Bates mix shows the unappreciable difference of approximately $150 \mathrm{lb} / \mathrm{in} .{ }^{2}$ due to the difference in vibration intensities. The intensities of vibration on the magnetic vibrator were adjusted to give final (and lowest) values of acceleration of 5.1 and $11.0 \mathrm{~g}$, approximating the accelerations of 4.2 and $10.5 \mathrm{~g}$ of the rotary vibrator.

When compacted on the rotary vibrator, the batch reproducibilities of the two Bates mixes are about equal, and much better than the Pearson mix. The batch reproducibility of the Bates mixes was better on the rotary than on the magnetic vibrator.

From a study of the results of the tests summarized in tables 2 and 3 , it may be concluded that the mixes with only cement and standard Ottawa sand had slightly better batch reproducibility than any of the other mixes.

(2) Effect of duration, amplitude, and frequency of vibration.-A series of tests was made of a 1:3.5 standard Ottawa sand mortar, 10 percent water, to study the effect of duration and speed on compaction and strength. The mortars were compacted on the rotary vibrator (amplitude of vibration 0.007 in. at speeds of 33 to $87 \mathrm{c} / \mathrm{s}$ and with durations of from 20 to $90 \mathrm{sec}$ ). The results of the tests are summarized in table 4.

Little strength was gained by vibrating for more than 40 sec. In general, the strength dispersion at $33 \mathrm{c} / \mathrm{s}$ was about that for handcompacted specimens and, for speeds of $50 \mathrm{c} / \mathrm{s}$ or greater, was approximately half this value. The greatest strength was attained in all cases in 90 sec of vibration. The strength increased with the frequency of vibration by an amount which decreased in approaching the top speed of $83 \mathrm{c} / \mathrm{s}$.

Some insight into the degree of compaction may be gained from the percentage of air voids in the specimens. The mortar, if completely compacted, would have, theoretically, no voids. According to table 4 the percentage of air voids ranged from 12.3 to 16.7. None of the mortars were therefore completely compacted; but those compacted at the two higher speeds had less voids than those compacted, for the same duration, at $50 \mathrm{c} / \mathrm{s}$, and those compacted at $50 \mathrm{c} / \mathrm{s}$ had less voids than those compacted for equal durations at $33 \mathrm{c} / \mathrm{s}$. Moreover, the longer the vibration, in general, the less the voids, for any one frequency of vibration. There is a definite correlation between the strength of the specimen and the quantity of air voids.

Additional data on the effect of amplitude, frequency, and duration of vibration on compaction were furnished by the three "pebble" mortars (see table 3). In these mortars the change in strength by vibrating longer than 30 sec was slight.

(3) Study of standard Ottawa sand mortars.-The preliminary studies having indicated the general type of mortars that would be most satisfactory for compaction, and the necessary vibration characteristics, another series (table 5) was prepared primarily to measure the reproducibility or uniformity of strength of individual specimens and of batches. The proportions used in this latter study were $1: 3$, $1: 3.5,1: 4$, and 1:4.5, parts of cement to parts of standard Ottawa 20-30 sand, by weight. With each proportion four different water contents were used-namely 9.0, 9.5, 10.0, and 10.5 percent of water by weight of the dry mix. Mortars were compacted at one amplitude 
on the magnetic vibrator and at two amplitudes at two speeds on the rotary vibrator.

Two methods of filling the molds were used: The first consisted in filling the molds to heaping and then vibrating them, and the second consisted in filling the molds in three layers while they were vibrating.

The values marked with asterisks indicated cubes which were not homogeneously compacted and had defective top portions. These cubes will not be considered in the discussion. Figure 4 shows one cube from each of the 16 groups which were compacted on the rotary vibrator at $40 \mathrm{c} / \mathrm{s}$ by vibrating the molds after filling; a number of cubes in this figure have defective tops.

TABLE 5.-Characteristics of standard Ottawa sand (20-30) mortars compacted by two vibrators by two methods of filling molds

[Duration of vibration, 1 minute. Specimens tested at 7 days. Each strength given is the average of 6 batches of 6 cubes]

\begin{tabular}{|c|c|c|c|c|c|c|c|c|c|c|c|}
\hline \multirow{3}{*}{$\begin{array}{l}\text { Propor- } \\
\text { tions by } \\
\text { weight }\end{array}$} & \multirow{3}{*}{$\begin{array}{c}\text { Water } \\
\text { con- } \\
\text { tent }\end{array}$} & \multicolumn{5}{|c|}{ Molds vibrated as filled } & \multicolumn{5}{|c|}{ Molds filled, then vibrated } \\
\hline & & \multirow{2}{*}{$\underset{\text { voids }}{\text { Air }}$} & \multirow{2}{*}{$\begin{array}{l}\text { Com- } \\
\text { pressive } \\
\text { strength }\end{array}$} & \multicolumn{3}{|c|}{$\begin{array}{l}\text { Strength } \\
\text { dispersion }\end{array}$} & \multirow{2}{*}{$\begin{array}{c}\text { Air } \\
\text { voids }\end{array}$} & \multirow{2}{*}{$\begin{array}{l}\text { Com- } \\
\text { pressive } \\
\text { strength }\end{array}$} & \multicolumn{3}{|c|}{$\begin{array}{c}\text { Strength } \\
\text { dispersion }\end{array}$} \\
\hline & & & & $C_{\mathrm{b}}$ & $\bar{C}_{\mathrm{b}}$ & $C_{i}$ & & & $C_{\mathrm{b}}$ & $\overline{C_{b}}$ & $C_{i}$ \\
\hline \multicolumn{12}{|c|}{ Rotary vibrator-frequency, $40 \mathrm{c} / \mathrm{s}$; amplitude, 0.031 in.; acceleration, $5 g$} \\
\hline $\begin{array}{l}1: 3 \\
1: 3 \\
1: 3 \\
1: 3\end{array}$ & \begin{tabular}{|r|} 
Percent \\
9.0 \\
9.5 \\
10.0 \\
10.5
\end{tabular} & $\begin{array}{r}\text { Percent } \\
7.8 \\
7.0 \\
8.3 \\
8.6\end{array}$ & $\begin{array}{c}l b / i n . .^{2} \\
a \quad 6,370 \\
6,130 \\
5,290 \\
4,740\end{array}$ & $\begin{array}{l}2.5 \\
2.5 \\
2.9 \\
2.3\end{array}$ & $\begin{array}{r}3.0 \\
0.8 \\
.9 \\
.9\end{array}$ & $\begin{array}{l}7.3 \\
2.0 \\
2.3 \\
2.1\end{array}$ & \begin{tabular}{|r|} 
Percent \\
10.7 \\
8.5 \\
9.2 \\
9.9
\end{tabular} & $\begin{array}{r}\text { lb/in. } \\
\text { a } 5,560 \\
5,740 \\
5,160 \\
4,740\end{array}$ & $\begin{array}{l}3.5 \\
3.2 \\
2.9 \\
3.4\end{array}$ & $\begin{array}{r}2.5 \\
1.1 \\
0.6 \\
.9\end{array}$ & $\begin{array}{l}6.1 \\
2.7 \\
1.5 \\
2.2\end{array}$ \\
\hline $\begin{array}{l}1: 3.5 \\
1: 3.5 \\
1: 3.5 \\
1: 3.5\end{array}$ & $\begin{array}{r}9.0 \\
9.5 \\
10.0 \\
10.5\end{array}$ & $\begin{array}{l}8.8 \\
7.4 \\
8.5 \\
8.8\end{array}$ & $\begin{array}{r}\text { a } 5,020 \\
\text { a } 4,930 \\
4,200 \\
3,680\end{array}$ & $\begin{array}{l}3.5 \\
1.7 \\
2.5 \\
1.9\end{array}$ & $\begin{array}{l}1.5 \\
0.7 \\
1.0 \\
0.9\end{array}$ & $\begin{array}{l}3.6 \\
1.8 \\
2.5 \\
2.3\end{array}$ & $\begin{array}{r}11.7 \\
9.9 \\
10.6 \\
10.1\end{array}$ & $\begin{array}{r}\text { a } 4,240 \\
\text { a } 4,390 \\
3,920 \\
3,540\end{array}$ & $\begin{array}{l}3.2 \\
3.1 \\
1.2 \\
2.1\end{array}$ & $\begin{array}{r}1.6 \\
0.9 \\
.8 \\
.7\end{array}$ & $\begin{array}{l}3.8 \\
2.3 \\
2.0 \\
1.8\end{array}$ \\
\hline $\begin{array}{l}1: 4 \\
1: 4 \\
1: 4 \\
1: 4\end{array}$ & $\begin{array}{r}9.0 \\
9.5 \\
10.0 \\
10.5\end{array}$ & $\begin{array}{r}13.5 \\
10.4 \\
8.1 \\
8.5\end{array}$ & $\begin{array}{r}2,980 \\
a 3,440 \\
\times 3,480 \\
3,010\end{array}$ & $\begin{array}{l}2.9 \\
1.7 \\
2.9 \\
1.2\end{array}$ & $\begin{array}{l}3.3 \\
2.2 \\
1.3 \\
0.8\end{array}$ & $\begin{array}{l}8.1 \\
5.5 \\
3.1 \\
2.0\end{array}$ & $\begin{array}{l}14.9 \\
12.5 \\
11.5 \\
10.6\end{array}$ & $\begin{array}{r}\text { a } 2,820 \\
\text { a } 3,030 \\
\text { a } 2,990 \\
2,750\end{array}$ & $\begin{array}{l}4.5 \\
3.1 \\
1.4 \\
1.6\end{array}$ & $\begin{array}{l}1.8 \\
1.9 \\
1.3 \\
0.7\end{array}$ & $\begin{array}{l}4.5 \\
4.6 \\
3.2 \\
1.7\end{array}$ \\
\hline $\begin{array}{l}1: 4.5 \\
1: 4.5 \\
1: 4.5 \\
1: 4.5\end{array}$ & $\begin{array}{r}9.0 \\
9.5 \\
10.0 \\
10.5\end{array}$ & $\begin{array}{r}15.7 \\
12.7 \\
10.1 \\
9.0\end{array}$ & $\begin{array}{l}\text { a } 1,980 \\
\therefore 2,350 \\
a 2,510 \\
a 2,320\end{array}$ & $\begin{array}{l}6.6 \\
7.8 \\
3.2 \\
1.9\end{array}$ & $\begin{array}{l}4.1 \\
3.1 \\
2.4 \\
1.6\end{array}$ & $\begin{array}{r}10.0 \\
7.6 \\
5.8 \\
4.0\end{array}$ & $\begin{array}{l}17.6 \\
14.3 \\
12.6 \\
11.7\end{array}$ & $\begin{array}{l}\text { a } 1,820 \\
a 2,090 \\
a 2,180 \\
a 2,010\end{array}$ & $\begin{array}{l}5.1 \\
5.9 \\
2.3 \\
2.6\end{array}$ & $\begin{array}{l}3.7 \\
2.5 \\
1.7 \\
1.3\end{array}$ & $\begin{array}{l}9.0 \\
6.1 \\
4.2 \\
3.2\end{array}$ \\
\hline \multicolumn{12}{|c|}{ Rotary vibrator-frequency, $83 \mathrm{c} / \mathrm{s}$; amplitude, 0.007 in.; acceleration, $5 g$} \\
\hline $\begin{array}{l}1: 3 \\
1: 3 \\
1: 3 \\
1: 3\end{array}$ & $\begin{array}{r}9.0 \\
9.5 \\
10.0 \\
10.5\end{array}$ & $\begin{array}{r}9.1 \\
10.1 \\
11.3 \\
11.6\end{array}$ & $\begin{array}{l}6,470 \\
5,660 \\
5,030 \\
4,570\end{array}$ & $\begin{array}{l}2.0 \\
2.6 \\
2.8 \\
2.8\end{array}$ & $\begin{array}{l}0.8 \\
1.2 \\
1.2 \\
1.2\end{array}$ & $\begin{array}{l}2.0 \\
3.0 \\
3.0 \\
3.0\end{array}$ & $\begin{array}{r}9.9 \\
10.6 \\
11.3 \\
11.6\end{array}$ & $\begin{array}{l}6,100 \\
5,530 \\
4,970 \\
4,590\end{array}$ & $\begin{array}{l}3.1 \\
1.3 \\
4.0 \\
2.9\end{array}$ & $\begin{array}{r}0.9 \\
.9 \\
.6 \\
1.0\end{array}$ & $\begin{array}{l}2.2 \\
2.1 \\
1.6 \\
2.4\end{array}$ \\
\hline $\begin{array}{l}1: 3.5 \\
1: 3.5 \\
1: 3.5 \\
1: 3.5\end{array}$ & $\begin{array}{r}9.0 \\
9.5 \\
10.0 \\
10.5\end{array}$ & $\begin{array}{l}11.3 \\
11.6 \\
12.7 \\
12.2\end{array}$ & $\begin{array}{l}4,840 \\
4,300 \\
3,900 \\
3,490\end{array}$ & $\begin{array}{l}2.0 \\
1.1 \\
2.1 \\
0.7\end{array}$ & $\begin{array}{r}0.9 \\
.9 \\
1.1 \\
1.0\end{array}$ & $\begin{array}{l}2.3 \\
2.3 \\
2.8 \\
2.5\end{array}$ & $\begin{array}{l}11.7 \\
12.4 \\
12.7 \\
12.6\end{array}$ & $\begin{array}{l}4,700 \\
4,260 \\
3,820 \\
3,460\end{array}$ & $\begin{array}{r}1.3 \\
1.8 \\
0.9 \\
.8\end{array}$ & $\begin{array}{r}0.7 \\
.6 \\
.8 \\
.9\end{array}$ & $\begin{array}{l}1.8 \\
1.4 \\
2.0 \\
2.3\end{array}$ \\
\hline $\begin{array}{l}1: 4 \\
1: 4 \\
1: 4 \\
1: 4\end{array}$ & $\begin{array}{r}9.0 \\
9.5 \\
10.0 \\
10.5\end{array}$ & $\begin{array}{l}10.9 \\
12.5 \\
12.8 \\
12.7\end{array}$ & $\begin{array}{l}3,630 \\
3,190 \\
2,850 \\
2,540\end{array}$ & $\begin{array}{l}1.5 \\
1.4 \\
1.4 \\
1.6\end{array}$ & $\begin{array}{l}1.2 \\
1.4 \\
1.7 \\
1.3\end{array}$ & $\begin{array}{l}3.0 \\
3.5 \\
4.1 \\
3.3\end{array}$ & $\begin{array}{l}12.7 \\
12.9 \\
13.2 \\
12.7\end{array}$ & $\begin{array}{l}3,430 \\
3,070 \\
2,770 \\
2,520\end{array}$ & $\begin{array}{l}2.1 \\
1.7 \\
1.5 \\
1.3\end{array}$ & $\begin{array}{r}0.7 \\
.7 \\
1.2 \\
0.9\end{array}$ & $\begin{array}{l}1.8 \\
1.7 \\
3.0 \\
2.3\end{array}$ \\
\hline $\begin{array}{l}1: 4.5 \\
1: 4.5 \\
1: 4.5 \\
1: 4.5\end{array}$ & $\begin{array}{r}9.0 \\
9.5 \\
10.0 \\
10.5\end{array}$ & $\begin{array}{l}11.6 \\
12.6 \\
12.7 \\
12.5\end{array}$ & $\begin{array}{l}2,840 \\
2,460 \\
2,220 \\
2,020\end{array}$ & $\begin{array}{l}2.1 \\
3.0 \\
2.7 \\
2.6\end{array}$ & $\begin{array}{l}1.3 \\
1.3 \\
1.8 \\
2.0\end{array}$ & $\begin{array}{l}3.1 \\
3.3 \\
4.5 \\
4.9\end{array}$ & $\begin{array}{l}13.3 \\
13.3 \\
13.0 \\
13.3\end{array}$ & $\begin{array}{l}2,700 \\
2,430 \\
2,200 \\
1,960\end{array}$ & $\begin{array}{l}2.1 \\
3.0 \\
2.1 \\
3.8\end{array}$ & $\begin{array}{r}.8 \\
.8 \\
.8 \\
1.2\end{array}$ & $\begin{array}{l}2.0 \\
2.0 \\
2.1 \\
2.9\end{array}$ \\
\hline
\end{tabular}

- Specimen showed segregation and was not included in discussion. 
TABLE 5.-Characteristics of standard Ottawa sand (20-30) mortars compacted by two vibrators by two methods of filling molds-Continued

\begin{tabular}{|c|c|c|c|c|c|c|c|c|c|c|c|}
\hline \multirow{3}{*}{$\begin{array}{l}\text { Propor- } \\
\text { tions by } \\
\text { weight }\end{array}$} & \multirow{3}{*}{$\begin{array}{l}\text { Water } \\
\text { con- } \\
\text { tent }\end{array}$} & \multicolumn{5}{|c|}{ Molds vibrated as filled } & \multicolumn{5}{|c|}{ Molds filled, then vibrated } \\
\hline & & \multirow{2}{*}{$\underset{\text { voids }}{\text { Air }}$} & \multirow{2}{*}{$\begin{array}{l}\text { Com- } \\
\text { pressive } \\
\text { strength }\end{array}$} & \multicolumn{3}{|c|}{$\begin{array}{l}\text { Strength } \\
\text { dispersion }\end{array}$} & \multirow{2}{*}{$\underset{\text { voids }}{\text { Air }}$} & \multirow{2}{*}{$\begin{array}{l}\text { Com- } \\
\text { pressive } \\
\text { strength }\end{array}$} & \multicolumn{3}{|c|}{$\begin{array}{c}\text { Strength } \\
\text { dispersion }\end{array}$} \\
\hline & & & & $C_{b}$ & $\overline{C_{b}}$ & $C_{i}$ & & & $C_{\mathrm{b}}$ & $\bar{C}_{b}$ & $C_{i}$ \\
\hline \multicolumn{12}{|c|}{$\begin{array}{c}\text { Magnetic vibrator-frequency, } 120 \mathrm{c} / \mathrm{s} ; \text { amplitude, } 0.0074 \mathrm{in} \text {.; accelera- } \\
\text { tion, } 5 \mathrm{~g}\end{array}$} \\
\hline $\begin{array}{l}1: 3 \\
1: 3 \\
1: 3 \\
1: 3\end{array}$ & $\begin{array}{r}\text { Percent } \\
9.0 \\
9.5 \\
10.0 \\
10.5\end{array}$ & $\begin{array}{r}\text { Percent } \\
6.5 \\
6.1 \\
6.2 \\
5.7\end{array}$ & $\begin{array}{c}\text { lb/in. } .^{2} \\
6,800 \\
6,500 \\
5,930 \\
5,330\end{array}$ & $\begin{array}{l}2.5 \\
3.0 \\
4.7 \\
2.0\end{array}$ & $\begin{array}{l}1.5 \\
3.9 \\
5.3 \\
4.1\end{array}$ & $\begin{array}{r}3.7 \\
9.6 \\
13.1 \\
10.1\end{array}$ & $\begin{array}{r}\text { Percent } \\
6.5 \\
6.6 \\
6.9 \\
7.7\end{array}$ & $\begin{array}{c}\text { lb/in. } \\
6,810 \\
6,280 \\
5,840 \\
5,100\end{array}$ & $\begin{array}{l}2.2 \\
2.1 \\
2.8 \\
3.5\end{array}$ & $\begin{array}{l}1.3 \\
2.7 \\
4.7 \\
4.4\end{array}$ & $\begin{array}{r}3.2 \\
6.7 \\
11.4 \\
10.8\end{array}$ \\
\hline $\begin{array}{l}1: 3.5 \\
1: 3.5 \\
1: 3.5 \\
1: 3.5\end{array}$ & $\begin{array}{r}9.0 \\
9.5 \\
10.0 \\
10.5\end{array}$ & $\begin{array}{l}7.6 \\
6.6 \\
5.9 \\
6.2\end{array}$ & $\begin{array}{r}5,370 \\
5,200 \\
4,750 \\
4,190\end{array}$ & $\begin{array}{l}2.2 \\
1.5 \\
2.9 \\
3.0\end{array}$ & $\begin{array}{l}2.2 \\
3.8 \\
4.1 \\
5.1\end{array}$ & $\begin{array}{r}5.3 \\
9.2 \\
10.1 \\
12.5\end{array}$ & $\begin{array}{r}9.4 \\
8.3 \\
9.4 \\
10.0\end{array}$ & $\begin{array}{r}a 5,020 \\
4,940 \\
4,320 \\
3,730\end{array}$ & $\begin{array}{l}1.9 \\
2.9 \\
4.3 \\
3.6\end{array}$ & $\begin{array}{l}1.8 \\
3.5 \\
5.7 \\
4.5\end{array}$ & $\begin{array}{r}4.3 \\
8.6 \\
13.9 \\
11.0\end{array}$ \\
\hline $\begin{array}{l}1: 4 \\
1: 4 \\
1: 4 \\
1: 4\end{array}$ & $\begin{array}{r}9.0 \\
9.5 \\
10.0 \\
10.5\end{array}$ & $\begin{array}{r}10.5 \\
9.2 \\
7.3 \\
5.9\end{array}$ & $\begin{array}{r}\text { a } 3,510 \\
\text { a } 3,540 \\
3,480 \\
3,210\end{array}$ & $\begin{array}{l}2.5 \\
3.6 \\
1.8 \\
3.0\end{array}$ & $\begin{array}{l}2.5 \\
2.6 \\
2.9 \\
3.2\end{array}$ & $\begin{array}{l}6.1 \\
6.4 \\
7.2 \\
7.8\end{array}$ & $\begin{array}{r}12.0 \\
10.4 \\
9.0 \\
8.5\end{array}$ & $\begin{array}{r}a 3,300 \\
a 3,240 \\
3,200 \\
2,960\end{array}$ & $\begin{array}{l}1.3 \\
3.1 \\
2.0 \\
2.4\end{array}$ & $\begin{array}{l}1.8 \\
2.1 \\
4.1 \\
5.6\end{array}$ & $\begin{array}{r}4.5 \\
5.1 \\
10.0 \\
13.8\end{array}$ \\
\hline $\begin{array}{l}1: 4.5 \\
1: 4.5 \\
1: 4.5 \\
1: 4.5\end{array}$ & $\begin{array}{r}9.0 \\
9.5 \\
10.0 \\
10.5\end{array}$ & $\begin{array}{r}12.0 \\
10.6 \\
8.8 \\
7.3\end{array}$ & $\begin{array}{r}a 2,610 \\
a 2,570 \\
a 2,590 \\
2,470\end{array}$ & $\begin{array}{l}3.6 \\
1.8 \\
2.4 \\
2.1\end{array}$ & $\begin{array}{l}1.6 \\
1.4 \\
2.2 \\
2.7\end{array}$ & $\begin{array}{l}3.9 \\
3.4 \\
5.5 \\
6.7\end{array}$ & $\begin{array}{r}13.7 \\
12.3 \\
10.4 \\
8.6\end{array}$ & 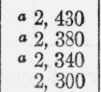 & $\begin{array}{l}3.2 \\
2.6 \\
4.5 \\
4.3\end{array}$ & $\begin{array}{l}2.5 \\
1.3 \\
2.5 \\
4.1\end{array}$ & $\begin{array}{r}6.0 \\
3.3 \\
6.1 \\
10.0\end{array}$ \\
\hline
\end{tabular}

a Specimen showed segregation and was not"included in discussion.

All cubes compacted at $83 \mathrm{c} / \mathrm{s}$ on the rotary vibrator were homogeneous and free from visible defects. Of the 32 groups compacted at $40 \mathrm{c} / \mathrm{s}$ on this vibrator, 20 showed nonuniform compaction. Of the 32 groups compacted on the magnetic vibrator, 12 had defective tops. Although this is somewhat better than the results obtained on the rotary vibrator operated at $40 \mathrm{c} / \mathrm{s}$, it is far short of the performance of the rotary vibrator operated at $83 \mathrm{c} / \mathrm{s}$ where all specimens were homogeneously compacted. If the standard sand test mortars were completely compacted into the molds, theoretically there would be enough cement and water to completely fill the interstices in the sand only for the 1:3 mortars and the two wetter 1:35 mortars; there would be up to approximately 6.5 percent of unfilled space, or air voids, in the remaining mortars. Table 4 shows that the measured percentage of air voids after compaction on the rotary vibrator exceeded the theoretical value, and furthermore that the air voids increased with water content instead of decreasing as the theoretical values. Of the cubes compacted at $83 \mathrm{c} / \mathrm{s}$ on the rotary vibrator the air voids were with two exceptions greater than 10 percent, and, for like mortars, greater than the voids in cubes compacted on the same vibrator at $40 \mathrm{c} / \mathrm{s}$, or compacted on the magnetic vibrator.

For the cubes compacted on the rotary vibrator at $83 \mathrm{c} / \mathrm{s}$ there was little difference in the amount of voids in the cubes made by the two methods of filling the molds, except for the 1:4.5 mortar and the driest 1:4 mortar, in which case those made by vibration during filling had somewhat lower voids.

The range of strengths obtained by the standard sand mortars of table 5 is from 1,960 to $6,810 \mathrm{lb} / \mathrm{in}^{2}$. For each cement:sand ratio the strength decreased with increase in water content. The strengths 
increased with increase in richness in cement, the four mortars of any one richness being stronger than those of the next leaner mix, except that the wettest mortar of the richer mix had slightly less strength than the driest mortar of the next leaner mix.

The strengths obtained on the specimens made by filling the vibrating molds, $40 \mathrm{c} / \mathrm{s}$ on the rotary vibrator, or on the magnetic vibrator, have a tendency to be higher than the strengths of specimens made by vibrating after filling the molds. However, as with the air-void content, the strengths obtained on the rotary vibrator at $83 \mathrm{c} / \mathrm{s}$ were practically the same for the two methods of mold filling. The independence of the strength from the method of mold filling is of advantage in a standard test method.

The 1:4 mortar, 10 percent mixing water, compacted on the rotary vibrator at $83 \mathrm{c} / \mathrm{s}$, gave strengths of approximately $2,800 \mathrm{lb} / \mathrm{in}^{2}$, that with 9.5 percent of mixing water $3,100 \mathrm{lb} / \mathrm{in}^{2} .^{2}$. These strengths approximate that of the plastic mortar cubes of SS-C-158, and also the strengths of the representative concrete with $C / W=1.7$.

A relatively small number of groups of cubes made on the magnetic vibrator and on the rotary vibrator at $40 \mathrm{c} / \mathrm{s}$ was uniformly compacted; a satisfactory comparison of the relative reproducibility of the cubes compacted on the two vibrators and those compacted on the rotary vibrator at the two speeds could not be made. It would appear, however, that for cubes without visible defects, there is no essential difference between the strength reproducibility of cubes of any one mix and of any one water content compacted on the rotary vibrator operated at 40 and at $83 \mathrm{c} / \mathrm{s}$. The strength dispersion of batches compacted on the magnetic vibrator was somewhat greater than that of batches compacted on the rotary vibrator. The reproducibility of the strengths of individual specimens on the rotary vibrator was far better than on the magnetic.

For cubes without segregation, there appeared to be but slight difference between the reproducibility of the cube batches, made by vibration after filling molds, over those filled during vibration.

The relation of the dispersion of individual strengths in the batch to the dispersion of the average strengths of batches is quite different for specimens compacted on the magnetic vibrator than it is for specimens compacted on the rotary vibrator. For the specimens compacted at $40 \mathrm{c} / \mathrm{s}$ on the rotary vibrator $C_{b}>\bar{C}_{b}$ for all 12 cases in which defects were not apparent. That is, the coefficient of variation of the batches was greater than it would have been if the variation of the average was due solely to the deviations of the individual cube strengths. This shows a batch-to-batch difference, which may be attributed to day-to-day variations in thoroughness of mixing, errors in proportioning, etc. In the specimens compacted at the higher speed $(83 \mathrm{c} / \mathrm{s})$, on the same vibrator, with 4 exceptions in the 32 different groups, the same characteristic prevailed, that is, $C_{b}>\bar{C}_{b}$.

On the other hand, for the 20 specimens compacted on the magnetic vibrator which had no visible defects, with 3 exceptions $C_{b}$ was less than $\bar{C}_{b}$. This might be attributed to some cause such as strength being a function of the position of the specimen on the vibrator. If this were true, the strength of a cube would be different for each of the six possible cube positions on the vibrator. Let us assume the extreme condition where the strength of the cube, although differing 
with the position, would be the same in any one of these positions from one batch to the next. Obviously the strength of the batches would then be the same, but there would be a positive and finite standard deviation $C_{t}$ of the individual cubes within the batch. In this case it is apparent that $\bar{C}_{b}$ computed from $C_{i}$ would be greater than $C_{b}$, which in this case is equal to zero.

In the tests no record was kept of the specimen location. A few batches made up to test the assumption that the strength is a function of location of the specimen on the vibrator were inconclusive, being obscured by the fact that $C_{b}$ has an appreciable magnitude. It was not thought worth the effort to make the comparatively large number of batches necessary to verify or disprove the assumption.

\section{SUMMARY AND CONCLUSIONS}

1. Two vibrators were employed in the investigation: (1) An electromagnetic vibrator having a fixed frequency of twice the frequency of the power supply. The amplitude varied with impressed voltage and also with the table weight so that, near resonance, where it was necessary to operate in order to compact the mortars, the amplitude varied as the mortars became compacted in the molds. (2) A rotary vibrator having a circular horizontal motion in which the speed of vibration could be adjusted up to a maximum of $83 \mathrm{c} / \mathrm{s}$. The amplitude could be adjusted with a maximum of 0.03 in. The mortars rotated in the molds during vibration. However, for all but the very driest mixes, the corners of the molds were completely filled. Studies with mortars of two colors showed that the motion did not produce internal segregation or intermixing except in specimens showing visible external segregation at the top.

2. The amount of rotation of the mortars on the rotary vibrator suggests itself as a measure of the consistency required for a mortar to be compacted by vibration, but the measurement was so tedious and subject to such experimental error that it is not recommended as a routine test method.

3 . The spread of the mortar on a flat plate attached to the vibrators was observed, as a possible method for measuring consistency. The outline of the spread mortar on the rotary vibrator was too irregular to warrant further consideration of the method on this vibrator.

4. The flow of wet mortars on the standard flow table is consistent, but that of the dry mixes erratic. A V-trough was designed for use with the rotary and also the magnetic vibrator, to measure the flows of dry mortars. This trough on the rotary vibrator was found to differentiate between the flows of dry mortars. Therefore, the V-trough may be used to measure the consistency of the drier mixes suitable for compaction by vibration, and the flow table for the wetter or "plastic" mixes.

5. Standard (20-30) Ottawa sand mortars appeared to have some desirable properties not found with other mixes for compaction by vibration, such as simplicity of proportioning and greater reproducibility of strength.

6. In standard Ottawa sand specimens compacted by vibrating from 20 to $90 \mathrm{sec}$ on the rotary vibrator at 33 to $83 \mathrm{c} / \mathrm{s}$, little strength was gained by vibrating longer than $40 \mathrm{sec}$, although the greatest 
strength was obtained in all cases by vibrating 90 sec. The strength increased as the frequency of vibration increased, but in progressively smaller steps.

7. Standard Ottawa sand mortars with proportions ranging from $1: 3$ to $1: 4.5$, with water contents of 9 to 10.5 percent, were compacted on each of the vibrators. The results of these tests may be summarized as follows:

a. All specimens made on the rotary vibrator at $83 \mathrm{c} / \mathrm{s}$ were apparently uniformly compacted. The drier and the leaner mixes when compacted on the magnetic vibrator or on the rotary vibrator at $40 \mathrm{c} / \mathrm{s}$ had defective upper portions.

b. The batch strength reproducibility of batches of the 1:3.5 and 1:4 mortars compacted on the rotary vibrator at $83 \mathrm{c} / \mathrm{s}$ was better than that of the 1:3 and 1:4.5 mortars. The average coefficient of variation $\left(C_{b}\right)$ of the strengths of the $1: 3.5$ and 1:4 mortars was approximately 1.5 percent, compared with 3.8 percent for the hand-compacted specimens made according to Federal Specification SS-C-158. The reproducibility of the specimens compacted on the rotary vibrator at $83 \mathrm{c} / \mathrm{s}$ was in most cases superior to that of similar specimens compacted on the magnetic vibrator or the rotary vibrator at $40 \mathrm{c} / \mathrm{s}$.

c. The strengths of the 1:4 standard Ottawa sand mortar, 9.5 and 10 percent mixing water, compacted on the rotary vibrator at $83 \mathrm{c} / \mathrm{s}$ were approximately 3,100 and $2,800 \mathrm{lb} / \mathrm{in}^{2}$, respectively. The strength of "plastic" mortar specimens hand-fabricated in accordance with Federal Specification SS-C-158 was 2,900 lb/in. ${ }^{2}$ This is approximating the strength of a 1:2.2:3.8 concrete of the same cement and with a $C / W$ ratio of 1.7 .

8. With few exceptions, the reproducibility of batches of mixes with all combinations of aggregates tested compacted on the rotary vibrator was superior to that of standard hand-compacted batches. In the mixes most suitable for vibration, the batch variation was less than half that of the hand-compacted specimens made of fine testing: sand.

\section{REFERENCES}

[1] William A. Blanchette, Some new relations bearing on concrete mixtures, Public Roads 15, 57 (May 1934).

[2] W. H. Glanville, and D. A. G. Reid, Mortar tests as a guide to the strength of concrete, Structural Eng. 12, 242 (1934).

[3] W. H. Glanville, Strength tests for cement, Structural Engr. (London) 15, 50 (1937).

[4] W. Edwards Deming, and Raymond T. Birge, Rev. Mod. Phys. 6, 119 (1934).

Washington, June 19, 1939. 